\title{
North-Country Flies
}

\section{UC-NRLF \\ |||||||||||||| ||| || || ||| |||||||| \\ |||||||||||||||||||||||||||||||||||||||||| \\ \$B 25 733}

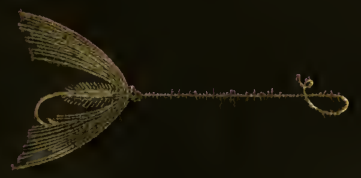

T, E, PRITT 


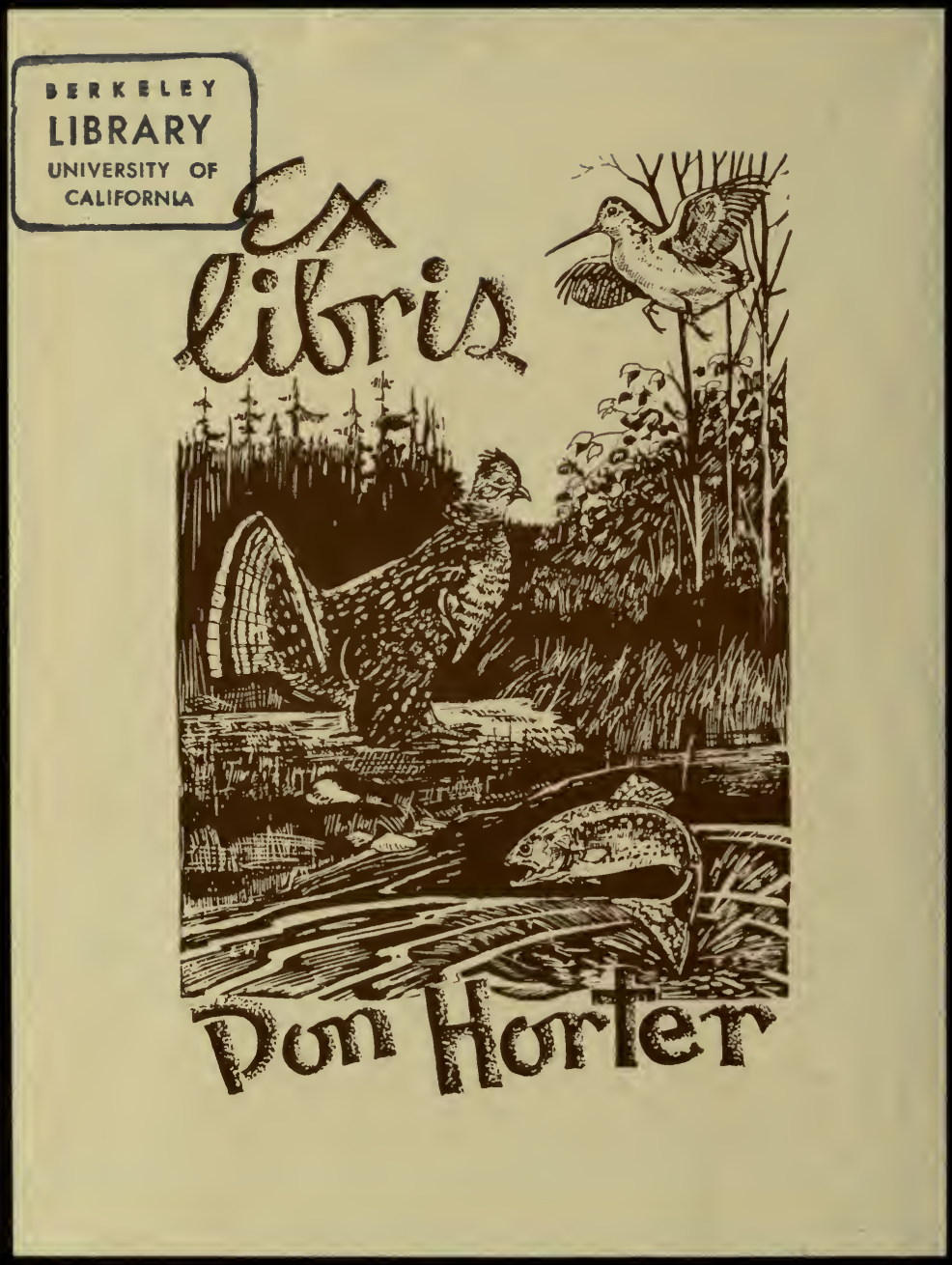



BERKELEY

LIBRARY

CALIFORNIA 
NORTH-COUNTRY FLIES. 
LONDON :

PRINTED BY GILBERT AND RIVINGTON, LIMITED, ST. JOHNS SQUARE. 


\section{NORTH-COUNTRY FLIES.}

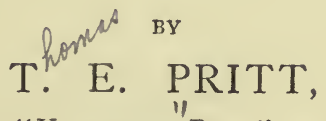

Angling Editor of the "Yorkshire Post," and Honorary Secretary, Yorkshire Anglers' Association. "

Comprising Eleven Plates of Hand-Painted Illustrations, from the Author's own Drawings, with Particulars of the

Dressings and Season of Each Fly;

and Chapters on Fishing the Minnow, the Creeper, the Stonefly, and the Worm in clear Water, with an Extra Plate SHOWING THE HOOKS NECESSARY THEREFOR.

SECOND EDITION.

YLOIDOII :

SAMPSON LOW, MARSTON, SEARLE, \& RIVINGTON, CROWN BUILDINGS, I88, FLEET STREET.

1886.

[All rights reserved.] 
Digitized by the Internet Archive in 2007 with funding from Microsoft Corporation 
To

\section{A HOST OF YORKSHIRE ANGLERS,}

GOOD FELLOWS,

AND

GOOD FISHERS ALL,

AND,

IN TOKEN OF

MY UNBOUNDED ADMIRATION

FOR THE

BEAUTIFUL RIVERS AND VALLEYS OF THE COUNTY, THIS BOOK

IS GRATEFULLY INSCRIBED

BY

THE AUTHOR. 



\section{PREFACE}

\section{TO THE FIRST EDITION.}

IT occurred to me, some three or four years ago, that there was again room in this great angling county for a book which should not only give the dressings and seasons of trout flies, but also add the best possible aid in the form of illustrations carefully and accurately coloured, in order to convey to the eye of the beholder correct impressions of the size, shape, and colours of those artificial flies which experience has proved are best adapted to the Yorkshire waters. It is a long stretch from the days of Theakston and Jackson to this present time, and in the interval there has grown up amongst observant anglers a decided preference for hackled flies, and wisely so, and this preference is by no means confined within the limits of our county. The production of such a work required, however, an amount of time which is not at 
the disposal of a man tied, as I am, to the cares and anxieties of business - and even an angler might well shirk the patient labour which it involved -so, after entertaining the idea for some time, I let it drop.

But in October, I 884, my brother anglers did me the very undeserved honour of placing me in the chair at the dinner of Yorkshire Anglers, held at the Queen's Hotel, in Leeds; and, during the course of the evening, an esteemed friend, who was aware of my former intention, again suggested the opening there was for a sufficiently comprehensive work on trout flies. A few days later the subject was again mentioned at a meeting of anglers, and, finding a unanimous opinion on the matter, I set to work. From that time to this every moment of my leisure, has been steadily employed, with what amount of success my readers and my brother anglers are the only judges.

It would be at once idle and unfair, on my part, to pretend that all that is set down in this book is the result of my own observation, knowledge, and experience; for much of it I am indebted to older 
heads than my own; still, since I first fished the Yorkshire waters, now more than twenty years ago, I have made a point of recording every matter of moment which I have noticed on the rivers, or have heard from my fellow-fishermen, and in this book the results of those observations are set forth. The chapter upon creeper-fishing - a branch of our beautiful art and recreation, which has hitherto been neglected in the county-may, I trust, have some influence in inducing Yorkshire anglers to take up this scientific and deadly method. For the rest, if there is nothing absolutely new, there is, I fervently hope, nothing worthless; and, having said this, it only remains for me to acknowledge my obligations to many kind friends in all parts of the county, and even further afield, who have been ever ready to assist me with their knowledge, and their counsel and advice; and, first amongst them, I would express my gratitude to Mr. William Naylor, of Keighley, to whom I am deeply indebted for his kindly help in the following pages; and to Mr. J. W. Reffitt, of Leeds, for his assistance in the patterns and sketches of minnow tackle; and Mr. Cadman, of Gomersal; and I must not forget the genial courtesy by which I 
have been allowed unlimited access to the unique collection of angling works in the Leeds Public Library; and Jerome Emmott, for many long years head keeper of the Kilnsey Angling Club, who dresses some of the most beautiful flies that can be found in all Britain, and long may he live to do so; and William Brumfitt, of Otley, an accomplished angler and excellent fly-dresser, who has grudged no pains in his efforts to assist me. To many other anglers and friends I am indebted in a lesser degree, though I am no less sensible of their kindness.

T. E. PRITT.

HeAdingley, LeEdS, 30th April, 1885. 


\section{PREFACE}

TO THE SECOND EDITION.

THE first edition of this work was published under the title of "Yorkshire Trout Flies." It was very generously received, and was quickly exhausted. But it was pointed out in quarters entitled to high respect that the title was too local: that the patterns of flies would do good service on all northern waters: that they would kill grayling as well as trout: and that the remarks upon Yorkshire streams would apply equally to all similar rivers.

In view of these representations it was therefore decided to alter the title to "North-Country Flies," the text remaining identical with that of the first edition.

This explanation is necessary in view of a perplexity which might arise in the minds of readers owing to the distinctly Yorkshire colouring which pervades the book.

HEADINGLEY,

$$
\text { T. E. PRITT. }
$$
I 886. 



\section{CONTENTS.}

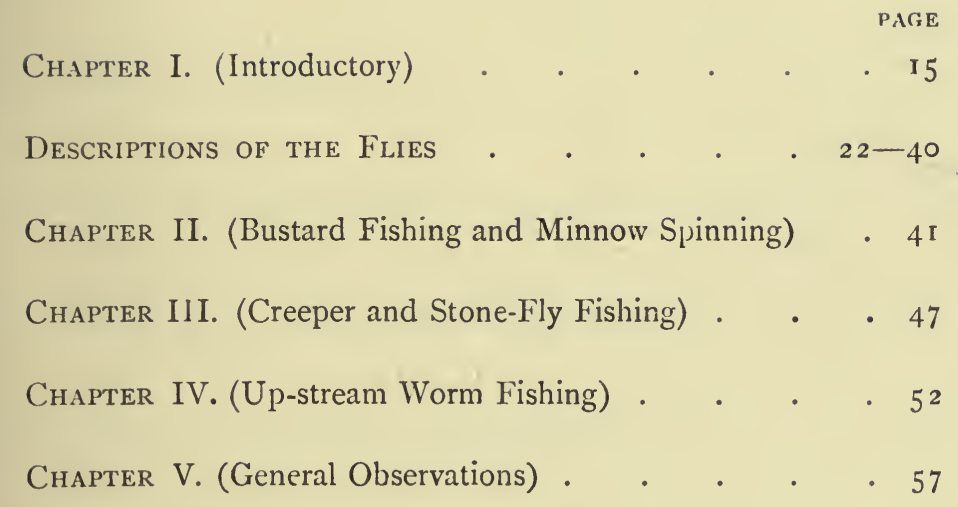





\section{CONTENTS.}
Chapter I. (Introductory)
Descriptions OF the Flies . . . . . $22-40$
Chapter II. (Bustard Fishing and Minnow Spinning) - $4 \mathrm{r}$
Chapter III. (Creeper and Stone-Fly Fishing) • • • 47
Chapter IV. (Up-stream Worm Fishing) • • . $\quad 52$
Chapter V. (General Observations) • . . . 57 


\section{LIST OF FLIES SHOWN ON THE PLATES.}

Plate I.-No. I. Water Cricket: No. 2. Little Black: No. 3. Winter Brown: No. 4. Little Winter Brown: No. 5. Brown Owl : No. 6. Fieldfare Bloa. See pages 22 and 23.

Plate II.-No. 7. Dark Moorgame: No. 8. Waterhen Bloa: No.9. Dark Bloa : No. Io. Dark Snipe. See pages 24 and 25.

Plate III.-Nos. II, I2, I3, I4, I5. March Brown. See pages 25 and 26.

Plate IV.-No. I6. Red Clock: No. I7. Red Palmer : Nos. I8, 19, 20, 2I. Little Dark Watchet (Iron Blue Dun). See pages 27 and 28.

Plate V.-No. 22. Dark Spanish Needle : No. 23. Light Spanish Needle : No. 24. Light Watchet: Nos. 25 and 26. Olive Bloas. See pages 29 and 30 .

Plate VI.-No. 27. Yellow-Legged Bloa : No. 28. Yellow Partridge : Nos. 29 and 30. Snipe Bloa: No. 31. Brown Watchet: No. 32. Orange Partridge. See pages $3 \mathrm{I}$ and 32.

Plate VII.-No. 33. Greentail: No. 34. Sandfly: No. 35 Dotterel: No. 36. Yellow Sally: No. 37. Poult Bloa: No. 38. Light Bloa. See pages 32 and 33 .

Plate VIII.-No. 39. Old Master: No. 40. Stone Midge : No. 4 I. Grey Midge: No. 42. Knotted Midge: No. 43. Sandy Moorgame : No. 44. Blue Partridge. See pages 34 and 35.

Plate IX.-No. 45. Red Owl : No. 46. Stone Bloa: No. 47. Small Blue Bloa: No. 48. Greensleeves: No. 49. Thornfly Dun:

No. 5o. Curlew. See pages 35,36 , and 37 .

Plate X.-No. 51. Starling Bloa: No. 52. Small Ant: No. 53.

Fog Black: No. 54. Cubdown Bloa: No. 55. Cinnamon: No. 56.

Smoke Fly. See pages 37 and 38 .

Plate XI.-No. 57. Grey Partridge : No. 58. Large Ant : No. 59.

Sea Swallow: No. 6o. July Dun : No. 61. Black Gnat: No. 62.

Black Snipe. See pages 39 and 40.

Plate XII.-Minnow, Worm, Creeper, and Stone-fly tackle. 


\section{NORTH-COUNTRY FLIES.}

\section{CHAPTER I.}

\section{INTRODUCTORY.}

THE resistless march of time, ruthlessly destroying the proudest works of man, has been insufficient to depose the Art of Angling from its position as the most primitive and the purest of all recreations. The most primitive, because, in this boastful nineteenth century, when we can measure the millionth part of a second, and call back the voices of the forgotten dead, we have little more actual knowledge of the ways and humours of fish than had our ancestors in the remote past: and the purest, because Nature herself lends every charm to glad the angler's soul and please his eye. Not in the grime of busy cities does the fisherman ply his silent art : not where the husky voice of Mammon crying "buy" rises above the roar of winds and storms : but out in God's fresh air, where rivers babble all day long, and birds are merry; where clouds repose upon the stately hill-tops and the whole soul goes out in gratitude and contentment at the smiling scene around.

From the very nature of the element in which fish have their being, it is evident that a too curious search into their habits must perforce be baffled: with their natural history and characteristics we are generally acquainted, but on questions which are of much greater moment to the angler 
-the minute causes which affect them and make a whole river-full of fish indifferent to any kind of food we can set before them-we know absolutely nothing. We know that most creatures feed at some part of each day, and that trout, as indeed all other kinds of fish, invariably do so: and that on some days they will feed ravenously upon surface food, and on others, very sparingly. In the latter event no doubt they make up the deficiency from the very minute larvæ and aquatic insects of all kinds with which the bottoms of our rivers are plentifully studded. In the vast majority of cases the very smallness of these living things defies any attempt at imitation : but what the invisible causes may be - the changes in the temperature of the water or the air; the colour of the sky; an instinctive knowledge that rain is coming, and will bring food in the fresh which follows : or of thunder which may be terrifying; or a score of other perplexities which have troubled the observant angler-we know not: we only know, and perhaps there is a charm in knowing it, that whereas to-day trout may feed upon winged insects greedily in the midst of a tempest of lightning and thunder, to-morrow, under precisely similar conditions, they will be sulky, sullen, and immovable.

It is not the purpose of this book to attempt to teach the art of fly fishing; the reader probably knows that experience is the only good master, though something of the fisherman's knowledge comes intuitively, and where the keen eye of one man will pick out the likely spots in a rippling stream, and see the quick rise of a trout, a hundred others will miss them, because, as the great father of fishers said, "angling is somewhat like poetry, man is to be born so." A few general remarks may not, however, be out of place, and it may first be briefly said that half the secret of success is the secret of keeping out of sight. A trout is wonderfully keen-sighted; in clear water he 
can see an amazing distance; on a bright summer's day he will scuttle off the shallows on the appearance of a figure fifty yards away, and rushing headlong past a hundred others, will give the signal and startle them all. Let it be remembered too that owing to the natural laws of refraction an angler is often visible upon the bank of a river long before he has any knowledge that he is within the line of sight of fish. It is a sound maxim therefore to keep as low as possible, and to get behind your prey.

On the great questions of fishing up, across, or down stream it is useless to enter; everything depends upon the size of the river, the condition of the water, and the nature of the bait. To fish up stream is an unnecessary labour in a discoloured water, and to fish down stream in a clear water is to court both disappointment and ridicule; for, in the latter case, except in a turbulent eddy or a broken rapid, the angler will be perfectly visible to every fish for many a yard below him.

There are, however, certain facts too frequently overlooked which it may be well to name, because on a knowledge and an observance of them, not a little of the angler's success will always depend. In the early part of the season the trout, in rivers such as we have in Yorkshire, will be found in the dubs or flats, and, unless the winter has been very mild, at the lower end of them ; in March and April as the fish gain strength they are nearer to the streams; as April progresses and aquatic insects and flies become more plentiful, and food more abundant, they acquire greater strength and get gradually into the lower parts of the stronger streams ; in May and June after feasting on the stone-fly, they are almost anywhere in the river except in the thins, in which latter you will find them in the blazing weather of July and August;; whilst in the latter part of August and September they are dropping down 
the rivers temporarily, and will be found most numerous in the lower parts of the streams preparatory to ascending the breeding becks. Then again, experience teaches that an angler need never despair of sport whatever quarter the wind may blow from, so long as it blows up stream; an upstream wind serves even a more important purpose than the provision of a ripple,-it keeps the feed on, and so long as there is food upon the water trout are on the look-out for it. If therefore you have your choice of two lengths of a river up one of which a steady wind is blowing whilst the other fails to catch it, always take the one with the wind upon it. For the same reason cast your flies as much as possible to that side of the river towards which the wind blows; the natural insects are blown thither and the trout are there. So too are trout collected under accumulations of froth; their instinct tells them it is a trap for flies and it is worth fishing. A trout will sometimes take any fly that is presented to him, but it is as well to remember that in nine cases out of ten he will not look at anything but the fly which is on the water so long as the rise is on. Fish hair if you like; it is not difficult to kill a very heavy fish with a single hair if your reel and running line are in good order, but it is difficult to get good hair of the proper transparency, length, and strength. The best is taken from the tail of the stallion, and very little of any other kind is good. Remember that you can always save a break by a big fish by an instant lowering of your rod point to a position parallel with the level of the stream, keeping the tip of your rod pointed at the fish; but there must be no hitch on your running line or reel. The advantages in fishing hair, except in the case of dropper flies, which stand better off the cast, are more imaginary than real. It is worth remembering that trout feed largely off the bottom of the river upon the pupæ and larvæ which are constantly 
on the move there. When they are so feeding, there is no food upon the surface, and their eyes are intent upon the bottom. At such times they rarely take an artificial fly well. The writer saw a handsome dish of trout taken in a northern river by an angler who fished caddis-baits-using two on a number 3 hook-and cast up stream, as you would fish a creeper.

In one important matter the fancy of Yorkshire anglers, and indeed of anglers all over the north of England, has undergone a change during the past twenty-five years. It is now conceded that a fly dressed hacklewise is generally to be preferred to a winged imitation. The reasons for this are not far to seek and are satisfactory. It is far more difficult to imitate a perfect insect and to afterwards impart to it a semblance of life in or on the water, than it is to produce something which is sufficiently near a resemblance of an imperfectly developed insect, struggling to attain the surface of the stream. Trout undoubtedly take a hackled fly for the insect just rising from the pupa in a half-drowned state; and the upening and closing of the fibres of the feathers give it an appearance of vitality, which even the most dexterous fly-fisher will fail to impart to the winged imitation. Moreover, trout are not accustomed to see perfect winged flies underneath the surface of the water; a drowned fly always looks drowned, and though hungry trout will sometimes take a winged fly very well, it will generally be found that the hackled flies account for the largest number of fish. Perhaps too much attention is commonly given to the wings of artificial flies, and too little to the bodies. These remarks it must be understood are written mainly of our Yorkshire and other north country rivers which abound in rippling streams and rough broken water. In the clear, smooth, gliding waters of the chalk streams of Hampshire and a few other counties, the case is 
different. There, fly-fishing as an art is perhaps at its greatest perfection, and to deceive the wary two or three or four pound trout which abound, say, in the Test, all the skill which the angler can bring to bear is required, and to accomplish this, it is often necessary to fish what is called the "dry" fly. In this the angler pins his faith on a single fly, a winged one, which he throws up stream over a rising fish, and so manipulates it as to bring it floating down the river with upright wings like a living fly. The hackled fly fished on such rivers would, of course, be out of place ; and whilst strongly leaning to hackles for our own rivers, there are times in big, bold waters, and when fishing imitations of large flies, when winged flies will sometimes kill quite as well as hackled, or spider-flies. One other point. Within reasonable limits, the flies for Yorkshire rivers, and for most other rivers of equal size,-for as the size of your river increases so, to a small extent, must your flies-cannot well be dressed too sparingly in the matter of feather. It stands to sense that to a creature with such wonderful vision as a trout it is better to err in offering a deception rather too small than too large. Do not make the mistake, though, of fishing hooks which are too small, or you will fail to strike your fish. You will find it worth while to examine your hooks every time you touch a fish and miss him. The point of a fish-hook is probably more liable to go than any other kind of steel, because the hooks are all pointed before they are hardened. You may remedy an accident of this kind with a bit of Arkansas whetstone, which you can get from any watch-maker and carry in your waistcoat pocket.

It will be noticed that several flies commonly fished on English rivers, notably the May-flies-the green and grey drakes, - the alder-fly and one or two others, are not included in this work. The beautiful insect known as the 
May-fly proper, which sits upon the water like some stately winged queen from fairy land, is not common in Yorkshire; specimens are annually seen, but there is no general rise of them throughout the three Ridings. The natural insect is fished by some expert anglers on certain rivers of the county,-notably the Ure, the Driffield Beck, and formerly the Aire. Of late years, however, it has been by no means numerous on the last-named river. It is a very deadly bait in skilful hands; but no imitations, not even the floating May-flies of the south-are ever very satisfactory to the fisherman. In the cases of a few other flies which are absent, they have been omitted because experience has proved that though any of them will kill, and perhaps kill well at times, they are not generally worth consideration.

It only remains to be said that the illustrations on the following plates have been very carefully copied from flies dressed by various Yorkshire makers. The originals, or others like them, have done service on half the rivers and lakes of England and Scotland, and have never failed to give a satisfactory account of themselves, despite the lugubrious warnings of local hands that "they were no use there." You will be told this probably on every new river visited; yet may you safely fish your own flies and laugh to scorn the dismal prophecies of anglers who believe that the trout in their own river differ in their choice of flies from those of any other river in the universe. 


\section{DESCRIPTIONS OF THE FLIES.}

(The seasons are given approximately, the actual time of the appearance and disappearance of each fy being dependent on the mildness of the previous winter and the prevailing spring weather.)

\section{Flies on Plate 1.}

No. I. WATER CRicket. Hook No. I.

WiNGS.-Hackled with a feather from the Golden Plover's breast, in its summer plumage, or the wing or back of a Starling.

BODY.-Yellow or Orange silk. It is sometimes ribbed with black silk.

In its early stages the insect of which this is supposed to be an imitation, is not a fly, but an active little spider. It runs upon the surface of the water, and is often taken greedily. The dressing shown in the plate is ample.

No. 2. Little Black. Hook O, short. WiNGS.-Hackled with a feather from a Black Cock's hackle or Starling's neck.

BoDy.-Purple silk, dubbed sparingly with Magpie herl. HEAD.-Purple.

This fly will kill quite as well as No. I. On very cold dull days in March and April, and again in August and September it will be found very useful. I have used it with great effect on Ullswater. 
PLATE 1.

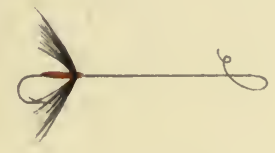

NOI. WATER CRICKET.

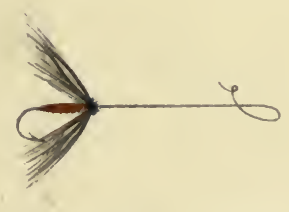

NN 3. WINTER BROWN.

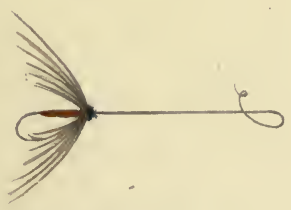

№.5. BROWN OWL.
MARCH .

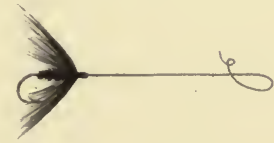

№ 2. LITTLE BLACK

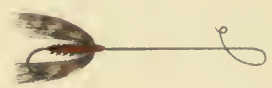

NO4 LITTLE WINTER BROWN OR LIGHT WOODCOCK.

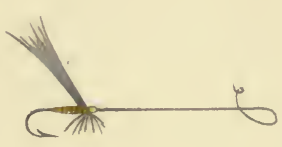

$N \cdot$ 6. FIELDFARE BLOA 

For the latter part of the season the following (not shown on the plate) is often used :-

WINGS.- Hackled with a feather from the outside of a Green Plover's wing, or a Swift's back.

BODY.-Black silk, sparely dubbed with black Ostrich herl.

No. 3. Winter Brown. Hook 2.

WINGS.-Hackled with a feather from the inside of a Woodcock's wing.

BoJjy.-Orange silk-not too bright.

HEAD.-Peacock herl.

A favourite early fly on all the Yorkshire rivers, killing well on wild, windy days in March and April. The wings assume a lighter shade in the course of ten days after its first appearance on the water, when it is commonly dressed as

No. 4. Little Winter Brown; or, Light WoODCOCK. Hook I.

Wings.-Hackled with a feather from the outside of a Woodcock's wing.

BODY.-Orange silk, with a spare dubbing of Hare's ear.

Jackson recommends for the later dressing a feather from a hen pheasant's wing, but the above is quite as good.

No. 5. BRown OwL. Hook I.

Wings.- Hackled with a reddish feather from the outside of a Brown Owl's wing.

BoDY.-Orange silk.

HEAD. - Peacock herl.

This is a capital killer and may be safely fished all the year round, dressed a trifle smaller as the season advances.

No. 6. Fieldfare Bloa. Hook i.

Wings.-From the bloa feather on a Fieldfare's rump, or failing that from the Tern, Bluetail, or Jay. 
BODY.-Yellow silk.

LEGS.-From a feather from the Golden Plover.

Kills well during the latter part of March, and throughout April and May on rather warm days, with a wind. A favourite fly in Lancashire.

\section{Flies on Plate 2.}

No. 7. Dark Moor-game, or Orange Grouse, or FRECKLEd DUN. Hook O.

WINGS.-Hackled with a black and orange feather from the Red Grouse, the hen bird for preference. BODY.-Orange silk. HEAD.-Either orange silk, or Peacock herl.

A good fly during March and April, particularly in a brown water, when the river is clearing after a flood.

No. 8. WATER-hen BloA. Hook I. WINGS.-Hackled feather from the inside of a Water-hen's wing.

BODY.-Yellow silk, dubbed with the fur of the Water-rat.

This fly is identical with the blue dun of Ronalds, and is indispensable during March and April, and again towards the latter end of the season. It is also a useful grayling fly all through the winter months. No. 9 on the plate is another dressing of the same fly, and is a favourite in Upper Wharfedale. The hackled fly is, perhaps, preferable, as the real fly hatches out mainly on cold, windy days. If the day be warm the insect takes flight immediately on reaching the surface of the water; but if, as is commonly the case, the day is cold, it lingers on the surface, not completely hatched into perfect form, and is thus easily pounced upon by expectant trout. 
PLATE 2.

NARCH.

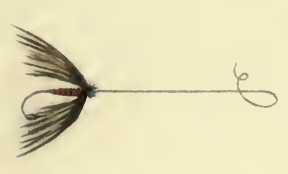

N07. DARK MOORGAME OR DRANGE GROUSE.

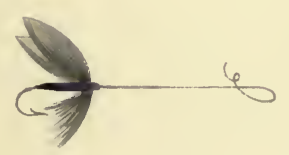

No 9. DARK BLOA.

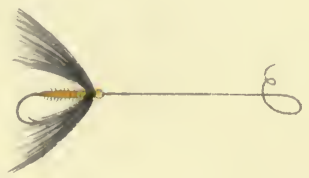

N: 8. WATERHEN BLOA

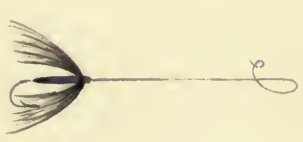

NO 10. DARK SNIPE 



\section{No. 9. DARK BLOA. Hook I.}

Wings.-From the Starling's quill.

BoDY.-Dark claret silk.

LEGS.-From black feather of a black Hen's neck.

Jackson dresses this fly somewhat similarly, and adds a tail as in the real insect. It is identical with one well-known and valued in the north as Broughton's point.

No. io. DARK SNipe. Hook I.

Wings.-Hackled with a feather from the outside of a Snipe's wing.

BoDy.-Purple silk.

A splendid killer on cold days in the early part of the season, and is a favourite on the Ribble.

In some districts it is not dressed until June, but the angler will find it too good to be neglected as a spring fly.

\section{Flies on Plate 3.}

March Browns (Great Brown, Brown Drake, Dun Drake).

\section{No. II. Hook 3.}

Wings.-From the tail of a Partridge.

BoDy.-Pale orange silk, dubbed with a little Hare's ear and yellow mohair, mixed; ribbed over with a little yellow silk.

TAIL-Forked with two strands from a Partridge's tail. LEGs.-From the back of a Partridge.

\section{No. I2. Hook 2.}

Wings.-Frcm a quill feather of a Hen Pheasant. BODY, TAIL, and LEGS as in No. II.

\section{No. I3. Hook 2.}

WiNGS.-Hackled with a reddish feather from the outside of a Woodcock's wing. 
BoDy.-Orange silk, dubbed over with a little fur from a Fox's ear.

No. 14. Hook 2.

Wings.-From the tail of a Partridge.

BoDY.-Orange and yellow silk twisted, dubbed with fur from a Fox's ear.

LEGS.-From a Wren's tail.

No. 15. Hook 2.

Wings.-From the Hen Pheasant's wing. BODY and LEGS.-Same as in No. I4.

The five dressings here given admit of little preference as killers. The hackled fly-though comparatively rarely dressed-will be found very useful on cold, rough days, and the winged flies are indispensable on fair days through March and April, and not infrequently into May. The female of the natural fly is a little lighter in the wing than the male, and a gradual change in the same direction appears to take place in the colour of all the flies as the season advances. Nos. 12 and 15 will therefore be useful later on, although if there is a heavy rise of the natural fly you will do well to have both the male and female fly on. Many anglers fish the March Brown, or a variation of it, more or less, all the year round, lessening the size as the months go on, and dressing it with a lighter feather, either from the grey goose or the hen pheasant. I have met many fishermen who believe that the fly which is often very abundant about the end of July or the beginning of August is in reality a second hatch of the March Brown. It is rather less and lighter in colour than the earlier hatchings, and like the latter changes to a red spinner. Jackson treats the later fly as an independent specimen, which he calls the August Brown, for which he gives a dressing almost identical with those I have quoted. Ronalds calls it the August Dun. 


\section{NORTH COUNTRY TROUT FLIES.}

PLATE 3

MARCH.
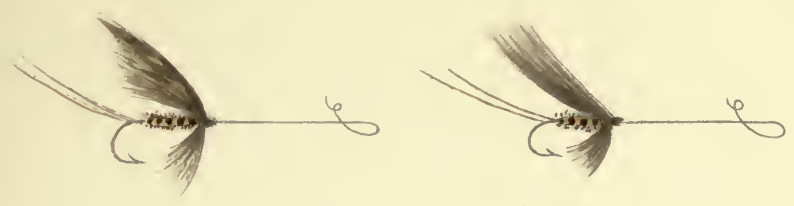

No 11

N. 12

No 13

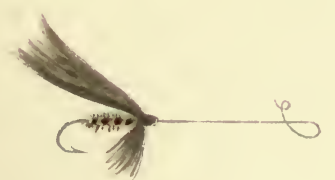

No 14

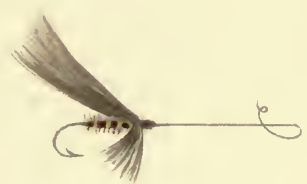

No 15.

MARCH BROWNS 

PLATE 4.

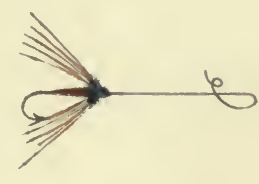

$$
\begin{aligned}
& \text { NO 16. RED CLOCK } \\
& \text { OR PHEASANT. }
\end{aligned}
$$

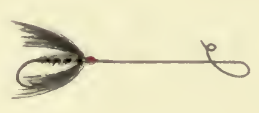

№ 18

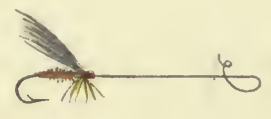

№. 20 .
MARCH \& APRIL.

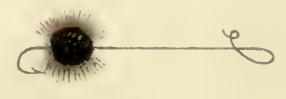

NO 17. RED PALMER

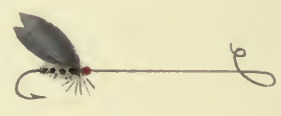

N. 19

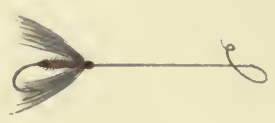

No. 21 .

Nos $18,19,20 * 21$, FOUR DRESSINGS OF THE LITTLE DARK WATCHET OR IRON BLUE DUN 
No. II is a very excellent fly, and I have proved its killing propertics not only on the Yorkshire rivers, but on the English and Scottish lakes, and notably on Loch Leven.

\section{Flies on Plate 4.}

No. 16. Red Clock or Pheasant. Hook I. Wings.-Hackled with a golden feather from a Cock Pheasant's neck, or from a small red cock's feather.

BOI)Y.-Yellow silk, with a twist of Peacock herl next the hackle.

HEAD.-Peacock herl.

Kills well sometimes on bright days in March and April.

No. 17. Red PALMER. Hook I.

BODY.-Green herl from Peacock, with a red cock's hackle wrapped over it.

This fly is best in a water which is fining after a flood, and occasionally it will be found very useful in a low clear river. I don't think it is a general favourite in Yorkshire, and it is only given because, whilst it will sometimes kill trout fairly, it is an excellent general grayling fly.

No. i8. Little Dark Watchet (Iron Blue Dun). Hook O short.

WINGS.-Hackled with a feather from a Jackdaw's neck, or outside a Coot's wing.

BODY.--Orange and purple silk twisted, dubbed with down from a Water-rat.

HEAD.-Orange.

No. 19. Hook O short.

Wings.-From a Water-hen.

BODY.-As in No. 18.

HEAD.-Ditto.

LEGS.-From a Coot. 


\section{No. 20. Hook O.}

Wings.-From the breast of a Water-hen.

BoDY.-Orange silk dubbed with Mole's fur.

HEAD.-Orange.

LEGS.-A dirty whitish brown from a Hen's neck, or hairs from a Calf's tail, dyed yellow.

\section{No. 2I. Hook O.}

Wings.-Hackled with a feather from Water-hen's breast ; or, if you can get it, from a feather from a Bluecap for preference.

BODY.-Orange silk, dubbed with Mole's fur. HEAD.-Orange.

Four dressings, varying little, but by different makers. No. 20 is a fanciful imitation of the natural insect, but it is an excellent killer.

This is a famous fly, and is known on most English rivers, and by a great variety of names-the iron blue dun, iron blue drake, little iron blue, little water-hen, little dark dun, \&c. Jackson calls it the pigeon blue bloa. In his "Book on Angling," Mr. Francis overlooks it in Jackson, and says, "Jackson does not give this fly till June, though all other authors introduce it in April." It is No. I4 on Jackson's plates, Mr. Francis having mistaken No. 39 for it. Jackson gives the dressing for his No. I4, almost identically with No. 20 as above, except that he adds the tail. On the Eden it is dressed from the breast of the cock Water-hen.

The natural fly appears on the Yorkshire rivers about the same time as the swallows first come, and the artificial fly will often kill well on cold days all through the season. The real fly comes out in vast numbers with any glint of sunshine from the middle of April to the end of May, and whilst it is on trout commonly prefer it to anything else. 

It is a very perfect little insect, and very beautiful to look at when it reaches the surface of the water, newly hatched. The male fly has a distinct crown of orange, or brownish red, which is also visible in the female, though not to an equal extent. The dark watchet is one of the daintiest morsels with which you can tempt a trout, and one of the most difficult to imitate satisfactorily.

\section{Flies on Plate 5.}

No. 22. Dark Spanish Needle (Needle Brozen). Hook O WINGS.-Hackled with a feather from the darkest part of a Brown Owl's wing.

BODY.-Orange silk. HEAD. - Peacock herl.

A good standard fly all through the season; but the natural insect cannot be imitated as a winged fly with any approach to a similitude to nature, owing to its diminutive size and the peculiar situation of its wings. Trout will often take it when few other flies will kill; the natural fly is most plentiful on the water on days with flying clouds and fitful bursts of sunshine, with a cold wind blowing underneath. Ronalds does not mention it. It is, however, a favourite in Yorkshire, particularly on the Rye, the Ure, and the Wharfe. It is often a capital killer on damp, close days in September, and will be found very useful as a grayling fly as far on as the beginning of December. The name "Needle" was probably given to it owing to the peculiar steely shade visible on the wings.

No. 23. Light Spanish NeEdle. Hook O. WiNGS.-Hackled with a feather from inside a Jack-Snipe's wing, or from the breast of a young Starling. BODY.-Crimson silk. HEAD.-Peacock herl. 
Another form of No. 22, more suitable for warm days. The shades of the natural flies vary considerably.

No. 24. Light Watchet (Spinning Jenny; Pearl Drake). Hook O.

WINGS.-From the Jay.

BoDY.-Straw-coloured silk.

LEGs.-Fibres from a Yellow Plover.

This is not a good fly to imitate. It is the metamorphosis of the dark watchet or iron blue dun, and both are often on the water together. Jackson calls it the little white spinner. It is a very delicate transparent insect, and most authorities are content to give a general instruction to dress it from the lightest dun hackle you can get. Most fly-dressers make some attempt to imitate the variations of colour in the extremities of the body of the natural insect, but the figure on the plate will kill well enough when trout are in the humour. Mr. Walbran remarks, in his "Notes" to Theakston, that he has never found the artificial fly kill well, and I know one fly-maker in the county who has ceased to dress it, in something like despair at his inability to produce an imitation of the natural fly to his satisfaction. It should be fished on mild days and in the evening during summer.

No. 25. Olive BloA. Hook I.

Wings.-From a Starling's quill.

BODY.-Greenish yellow silk.

LEGS.-White hackle from a Hen's neck, stained to olive in onions.

No. 26. Olive BloA. Hook O.

WiNGS.-Hackled with a feather from a Lapwing's back or rump.

BODY.-Yellow silk.

HEAD.-Orange silk. 
PLATE 6.

APRIL.

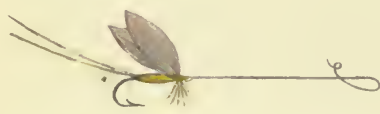

№ 27, YELLOW LEGG'D BLOA.

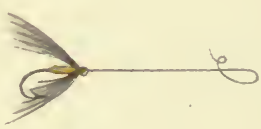

N. 29. SNIPE BLOA.

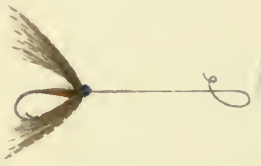

N. 3I. BROWN WATCHET

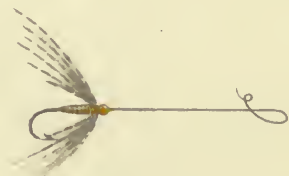

N: 28. YELLOW PARTRIDGE

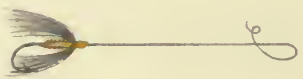

NO 30 SNIPE BLOA

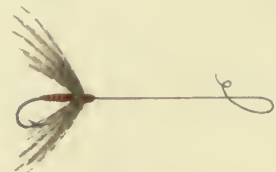

N. 32 ORANGE PARTRIDGE 
Known by a great variety of names, and always useful. Either of the forms here given will kill well on cold windy days, particularly about midday in March and April.

\section{Flies on Plate 6.}

No. 27. Yellow-Leg(ied BloA (Yellow Dun). Hook I. WingS.-From a young Starling's quill feather. BoDy.-Yellow silk, waxed well, so as to make it nearly olive.

LEGS.-Ginger hackle from a Cochin-China Hen's neck. TAIL.-Two strands of the above.

A first-rate killer, indispensable during its season.

No. 28. Yellow Partridge (Grey Gnat). Hook I. WINGS.-Hackled with a light feather from the back of a Partridge.

BODY.-Yellow silk.

A good killer almost any time during April.

No. 29. Snipe BíOA. Hook I.

WINGS.-Hackled with a feather from the inside of a Jack Snipe's wing.

BODY.-Straw-coloured silk.

No. 30. Snipe BlOA. Hook O.

Wings.-Hackled with feather from under Snipe's wing. BODy.-Yellow silk, with a spare dubbing of Mole's fur, but not sufficient to hide the yellow body.

Two dressings of the same fly, and practically identical. It is a splendid killer, and many anglers fish it more or less all the year round. It is Theakston's Bloa brown, and is probably to be identified with the Light Bloa of Jackson. It is fished universally in Yorkshire and Lancashire, and it will account for its share of fish at any time, and particularly on cold, wild days, all through the season. 
No. 3I. Brown Watchet (Little Brown Dun). Hook I. Wings.-Hackled with a well dappled feather from a Partridge's back.

BODY.-Orange silk.

HEAD.-Peacock herl.

No. 32. Orange Partridge. Hook i.

Wings.-Hackled as in No. $3 \mathrm{I}$.

BODY.-Orange silk.

These are practically the same flies, and are very excellent killers. I prefer the dressing of No. 32 myself, although one will kill as well as the other, and the angler may look upon one of them as indispensable on his cast from April to September, on warm days. It is the Turkey Brown of Ronalds, and the Spiral Brown Drake of Theakston.

\section{Flies on Plate 7.}

No. 33. Greentail (Grannom Fly). Hook I. Wings.-Hackled with a feather from the inside of a Woodcock's wing, or from a Partridge's neck, or from under a Hen Pheasant's wing.

BODY.-Lead coloured silk, twisted with a little fur from a Hare's face.

TAIL.-Green silk, wrapped over lower part of body.

This fly does not last very long, and appears to be quite extinct for the season in about eighteen days after its first appearance on the water. It is not always to be relied on as a killer, although, now and then, trout will make a dead set at it, and take nothing else. It kills best in the morning and evening, on warm days.

No. 34. Sandfly. Hook I.

Wings.-From a sandy feather from a Landrail's wing. 
NORIH COUNTRY TROUT FLIES.

\section{PLATE 7.}

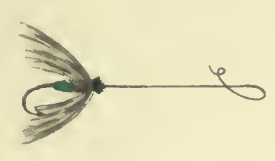

No 33. GREENTAIL.

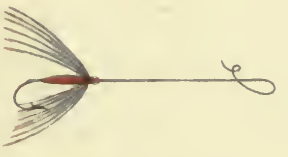

NN. 35. DOTTEREL.

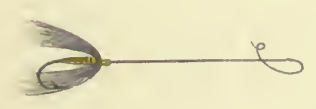

NO 37. POULT BLOA, OR

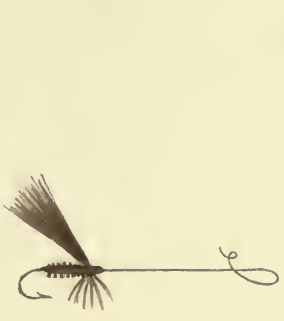

Nํ34. SANDFLY.

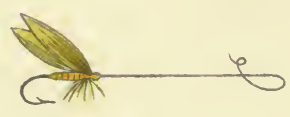

N: 36. YELLOW SALLY.

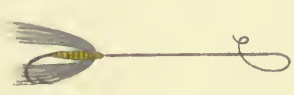

No38. LIGHT BLOA. 

BODY.-Light brown silk, ribbed with sandy fur from a Hare.

LEGS.-Dark ginger hackle.

This fly is commonly dressed rather large in the wing. It will not always kill. It does best in warm, gloomy weather, and sometimes with a moderate wind blowing on a dub it will be found useful. It is a favourite on the Ribble, where it is often taken well.

No. 35. DOTTEREL. Hook I.

WiNGS.-Hackled with a feather from the outside of a male Dotterel's wing.

BODY.-Straw-coloured silk; some anglers prefer Orange silk.

HEAD.-Straw-coloured, or orange silk.

This fly is undoubtedly a splendid killer, although it may be questioned whether its reputation on all the Yorkshirc, and other north country rivers, is not in excess of its merits. As a matter of fact a feather from a young curlew will be found equally attractive to the trout. The dotterel is a good standard fly all through the season from the end of April, more especially on rather cold days.

No. 36. Yellow Sally. Hook O.

WINGS.-From a Green Linnet's tail.

Bony.-Yellow silk.

LEGS.-White feather from a Hen's neck, dyed yellow in onions.

This fly is dressed on almost every Yorkshire river, and it is therefore included, but it rarely kills well, and the natural insect does not appear to be much relished by trout. Nos. 37 \& 38. Poult BloA, or Light BloA. Hook O. Wings.-Hackled with a feather from under the wing of a young Grouse. 
BODY.-Light yellow silk.

A fair killer on cold days all through the season. For warm days a fancy dressing of it, as under, will sometimes be found useful :-Wings, hackled as above; Body, strawcoloured silk, with a twist of purple silk round it; and a peacock herl head.

\section{Flies on Plate 8.}

No. 39. Old MASTER. Hook I.

WINGS.-Hackled with a feather from the inside of a Woodcock's wing.

BODY.-Ash-coloured silk, wrapped over with Heron's herl.

This is a capital killer from April to the end of August, on warm days, or in the evenings. It was originally dressed by Bradley, of Otley, and in his time he caught many heavy dishes of trout with it. It bears some resemblance to "Greenwell's Glory."

No. 40. Stone Midge. Hook O.

WINGS.-Hackled with a feather from a Pewit's neck, breast, or rump.

BODY.-Ash-coloured silk, dubbed sparely with Heron's herl.

HEAD.-Magpie herl.

The natural fly is not good to imitate owing to its diminutive size, but the above will kill well on cool days.

No. 4I. Grey MidGe. Hook O.

WINGS.-Hackled with a feather from a Woodcock's breast.

BODY.-Yellow silk.

HEAD.-Peacock herl.

Kills best on warm days, and summer evenings. 
PLATE 8.

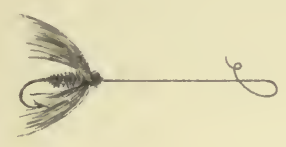

N. 39. OLD MASTER

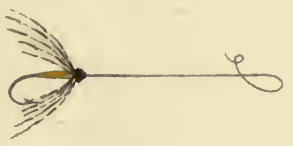

NO 4I. GREY MIDGE.

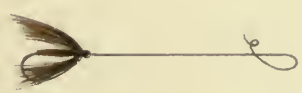

N.43. SANDY MOORGAME.
APRIL \& MAY.

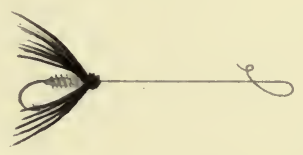

NO 40. STONE MIDGE

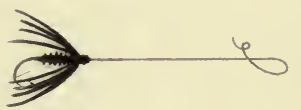

NN. 42. KNOTTED MIDGE.

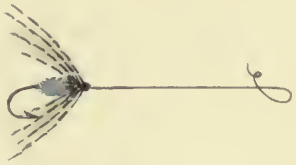

NN 44. BLUE PARTRIDGE 

No. 42. KNOtTed MidGe. Hook O.

WiNGS.-Hackled with a feather from the back of a Swift or Martin, or from the shoulder of a Pewit's wing.

BODY.-Ash-coloured silk, dubbed with Heron's herl, rather more fully than in No. 40.

HEAD.—Magpie herl.

Does very well sometimes on hot stuffy days, when thunder is about.

No. 43. Sandy Moorgame. Hook O. WINGS.-Hackled with a dark reddish-brown feather from the back of a Grouse.

BODY.-Dark brown silk.

HEAD.-Ditto.

This is a very useful fly from May to the end of July, and it is not to be neglected in a brown water clearing after a flood. It is probably identical with the dark dun of Theakston.

No. 44. Blue Partridge. Hook I. Wings.-Hackled with a feather from a Partridge's back. BODY.-Blue silk dubbed with a little lead-coloured lamb's wool.

A first-rate killer in a biggish water any time after the middle of May.

\section{Flies on Plate 9.}

No. 45. RED OwL (Brozen Dun). Hook I. Wings.-Hackled with a red feather from a Brown Owl's wing; shorter in the fibre than that used for No. 5 .

BODY.-Orange silk. HEAD._Peacock herl. 
A good killer in warm weather, particularly in the evening.

No. 46. Stone BloA. Hook O.

Wings.-From a feather from under a Jack Snipe's wing. BODY.-Yellow silk.

LEGS.-Fibres from a Jack Snipe's feather.

This fly is useful from the beginning of June until the end of the season; it kills well occasionally about mid-day, but is best as an evening fly.

No. 47. Small Blue Bloa. Hook O.

Wings.-From a feather from Bluecap's tail.

BODY.-Orange silk.

LEGS.-Pale yellow fibres.

I have been unable to identify this with any fly dressed by Jackson, Ronalds, Theakston, or others. Most of them give flies of almost similar names, and all of them differ greatly in the dressing. The fly here given will be found a good, all-round summer killer.

No. 48. Greensleeves. Hook I.

WiNGS.-Hackled with a feather from the inside of a Woodcock's wing or from a hen Pheasant's neck.

BODY.-Bright green silk.

HEAD.-Ditto.

Another form of Ronalds' "Gold-eyed gauze wing," useful only on dull, sultry days, and occasionally in the evening. Not generally dressed, but will now and then kill fairly.

No. 49. Thornfly Dun. Hook I.

WINGS.-Hackled, with a Landrail's feather, taken from under the wing.

BoDY.-Orange silk.

HEAD._Peacock herl. 


\section{NORTH COUNTRY TROUT FLIES.}

PIATE 9

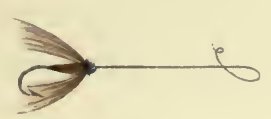

N:45. RED OWL.

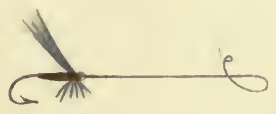

№ 47. SMALL BLUE BLOA

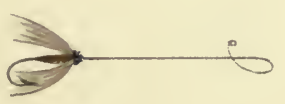

NO 49. THORNFLY DUN
MAY \& JUNE .

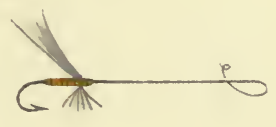

NN.46. STONE BLOA.

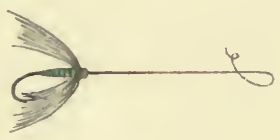

№ 48. GREENSLEEVES.

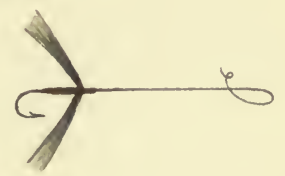

N:50. CURLEW. 

. 
NORTH COUNTRY TROUT FLIES.

PIATE 10.

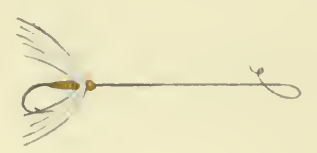

NN. 51. STARLING BLOA.

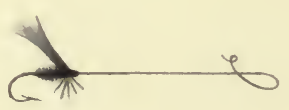

NN 53. FOG BLACK.

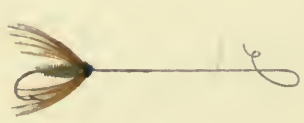

NO55. CINNAMON.
JUNE \& JUIY.

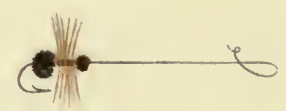

№ 52. SMALL ANT

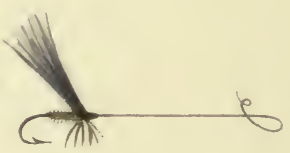

№ 54. CUBDOWN BLOA.

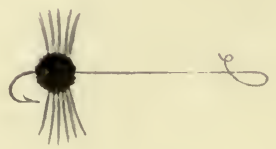

N056. SMOKE FLY 
A very excellent fly in a good bold brown water on warm days in summer, from June onwards. It is a variation of No. 5, and equally useful. Dressed with a redder feather it is the same fly as that known as Blacker's Red.

No. 50. Curlew. Hook O.

WINGS.-Hackled with a small feather from the outside of

a young Curlew's wing (August at the latest). BODY.-Orange silk for preference, but maroon or yellow will sometimes kill equally well.

The pattern for this fly was supplied to me by Mr. Henry Cadman, of Gomersal, who has dressed it for a good many seasons past. It will kill almost at any time, and particularly in a rather low and clear river. A feather from a Green Plover will kill, but the Curlew is better and should be used in preference.

Flies on Plate 10.

No. 51. Starling BlOA. Hook O.

WiNGS.-Hackled, with the lightest feather from a young Starling's wing.

BODY.-Straw-coloured silk. Some anglers prefer white silk.

Probably Jackson's "Nankeen Spinner." It will kill on cold days in May, and late in the evenings in June and July.

No. 52. Small ANT. Hook O.

WINGS.-Hackled with a feather from a Tomtit's tail. BODY AND HEAD.-A bright brownish Peacock's herl; body dressed full, as shown in the plate.

Is best on hot days in July and August. The natural fly is abundant on almost every English river, and the 
artificial fly is alluded to by most writers. It will now and then do great execution, particularly after a flight of ants.

No. 53. FOG BLACK. Hook O.

Wings.-From a Bullfinch's wing.

BODY.-Dark purple silk, dubbed with dark Heron's herl, or, more sparingly, with black Ostrich herl.

LEGS.-From the Starling's neck.

Suitable for cold dark days, from June to the end of the season. The natural fly is very diminutive, and the artificial must be kept as small as possible. A capital grayling fly.

No. 54. Cubdown BlOA. Hook I.

WingS.-From the inside of a Swift's wing, or from a Lapwing's apron.

BoDy.-Yellow silk, dubbed with down from a Fox cub, or fur from a Water-rat.

LEGS.-From a Plover's feather.

Useful towards evening through June and July.

No. 55. Cinnamon. Hook I.

Wings.- Hackled with a feather from a Brown Owl's wing. BoDY.-Yellow silk, dubbed with fur from a Water-rat. HEAD.-Peacock herl.

A capital summer fly, particularly in the evening. It is well known, and universally fished during July and August, in Yorkshire and Lancashire. Jackson says it is best taken in a shower.

No. 56. SMOKE Fly. Hook I.

Wings.-Hackled (as in the plate) with a feather from a young Grouse.

Bony.-Bright brown Peacock's herl. It is sometimes dressed with a twist of silver round the body. 
* 


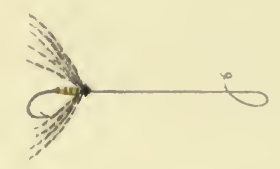

№ 57. GREY PARTRIDGE

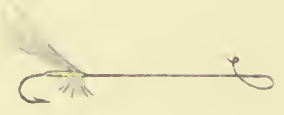

NO 59. SEA SWALLOW.

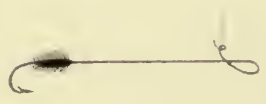

NN 6I. BLACK GNAT.

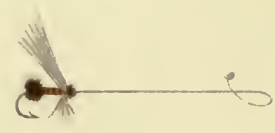

N.58. LARGE ANT

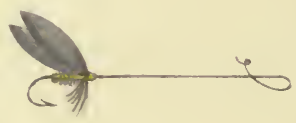

№60.JULY DUN.

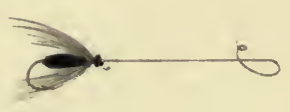

No 62. BLACK SNIPE 
More or less a fancy fly, and will only kill in certain curious states of the weather and the water. On sluggish water, in dull, heavy, sultry weather, it is sometimes useful.

\section{Flies on Plate 11.}

No. 57. Grey Partridge (Grey Watchet.) Hook O. Wings.-Hackled with a light feather from a Partridge's breast.

BODY.-Straw-coloured silk.

HEAD.-Peacock herl.

For cold days, and in the evenings during June and July. No. 58. Large ANT. Hook O.

Wings.-From a Starling's quill.

BODY.-Orange silk wrapped over the lower part, with three turns of a copper-coloured Peacock's herl, as shown in the plate.

HEAD.-Peacock's herl.

LEGS.-Fibres from the light part of a Starling's quill feather.

Kills best on warm days towards the latter part of the season. It is identical with Jackson's "Orange Stinger." The natural fly never appears in large numbers.

No. 59. Sea Swallow. Hook O.

WingS.-From a very light feather from the outside of a Sea Swallow's wing.

BoDy.-White silk.

LEGS.-Fibres from the wing feathers.

Mainly an evening fly.

No. 6o. July DuN. Hook I.

Wings.-From a Starling's quill.

BoDY.-Yellow silk dubbed with a little Mole's fur.

LEGS.-Fibre from a bluish dun Hen's neck. 
This is probably Jackson's little Olive Bloa, and is perhaps the same fly as Theakston's pale blue Drake. It is common on most English rivers, and trout will occasionally take it with great avidity.

No. 6I. Black Gnat. Hook O.-Short.

\section{WINGS.-None.}

BoDy.-A little Ostrich herl.

The diminutive size of the natural insect and the consequent difficulty in imitating it, is probably only one reason why anglers universally lament their inability to catch trout whilst the black gnat is on. As a matter of fact you may try trout with anything you like, but they will rarely be diverted from the natural fly. The specimen here given will kill as well as any other imitation, and it is quite big enough and sufficiently like a hackle imitation of the fly, without any attempt to add the wings.

No. 62. BlaCk Snipe. Hook O.

WINGS.-Hackled with a Jack Snipe's feather from under the wing.

BODY.-Dark green Peacock herl.

This is an old Yorkshire fly, quoted in many manuscripts on angling, still in existence, although it is not generally dressed. It will kill well almost all the year round, and my own experience has proved that it is a good general fly. 


\section{CHAPTER II.}

\section{Bustard Fishing and Minnow Spinning.}

IT may perhaps be worth while to say something in small compass on the very killing method of angling, little practised in Yorkshire, which is known as bustard fishing. The bustard is a large moth, white or brown, and may be dressed thus on a No. 4 or 5 hook. The White Bustard: wings from a White Owl's quill feather; body, white Berlin wool, ribbed with yellow silk, or gold tinsel; head, black Ostrich herl, used sparingly; legs, from a white cock's hackle. The Brown Bustard is thus dressed : wings, from a quill or tail feather of a Brown Owl; body, brown fur from a hare's neck, mixed with a little common worsted, and any brown hackle run all the way up it. These flies need not be spared in the dressings, and without illustrating them the size of hook will serve as a guide in the dressing of the fly.

Bustard fishing demands an amount of self-denial and general discomfort to which the writer, at least, is not equal, but very heavy baskets of large fish are often made by it when no other bait is looked at. Armed with one, or both of the moths described above, with a spare cast round your hat in case of accident, using a cast about six feet long, and throwing a line not much, if any, longer than your rod, you begin fishing as soon as it is perfectly dark. Trout will rarely take the bustard in the dusk, and on a summer's night, which is your only bustard time, you need scarcely 
look for sport much before midnight. You will find waders very useful, but there is no necessity to wade; you can fish with one foot on the bank and one in the water; things are by no means promising for this kind of fishing if you are compelled to seek the fish. When you are ready, fish the edges close to the shore, particularly where a ripple or an eddy breaks ; cast carefully under trees or banks, or any other likely hold, but the majority of your fish will come from near the shore at the edges of the streams. When a trout takes the bustard, he does it peculiarly,- -he makes no sound and he gives no tug; the only intimation you have that something has happened is a feeling as if some one had suddenly hung a half-pound weight on your line. Strike then instantly. By far the best fishing with this lure, and it is perhaps worthier of the angler's art, is had between dawn and sunrise in the roughish streams and rapids; then, of course, you must wade. Trout often rise ravenously at the moth in the very early morning, but the game is up at the same moment as the sun.

Minnow-fishing for trout is divided into two branches, in both of which the minnow is made to spin in the water. In one case it is used when the river is clearing after a flood, and in the other in clear water on bright days. Both are very deadly modes of angling, and the latter requires an amount of skill and judgment unsurpassed by any other branch of the fisherman's art. It is not proposed to do more than offer some general remarks upon the subject, because no amount of writing will teach a reader more than the mere rudiments of a practice which requires patience and observation at the river-side itself. In fishing a minnow in discoloured water, the difficulty is not great, but in clear water fishing you must serve a considerable apprenticeship to the business before you can hope for much success.

The most important essential in a minnow-fisher's outfit 
are his minnows. Artificial minnows of a dozen different kinds will kill, and some of them-notably the "Devon" and the blue "Phantom"-will sometimes kill very well, but the natural fish is always to be preferred before the finest imitation, or spinner, ever yet invented; and the fresher the minnow the better : that is, he should, if possible (and there is no difficulty about it), be alive and having all his silvery sheen about him up to the moment when you put him on the hooks. Kill him by a fillip on the head before you impale him, though observant fishermen are agreed that it is doubtful whether fish have more than the dullest sensibility to pain. It is within the experience of many anglers - the writer amongst them-to have hooked fish which have broken away with hooks and tackle, and to have caught them immediately afterwards with the purloined property in their possession.

There are various ways adopted by different fishermen for keeping minnows alive, or at least fresh, at the river side : you may preserve them in salt, which is never very satisfactory, because they lose colour and become soft : if you are obliged to preserve them, do so in spirits of wine. They will, however, keep alive for the best part of a day in an ordinary soda-water bottle, with a hole through the cork, if the angler keeps moving and so sufficientlyaerates the water. The best plan-indeed, the only thoroughly satisfactory and comfortable way-is to put your live minnows in damp moss, which should not be wet, only fairly damp, and enclose them in an ordinary May-fly box. With a few dampings in the course of a day they will keep alive and retain their sheen excellently, if you are careful not to let a hot sun fall upon your box for more than a minute or so at a time. The modes of baiting a minnow and the varieties of flights used are very great, but all of them are similar in principle, the main object being to produce an effectual spin and to pre- 
sent to the fish a bait armed with hooks so disposed that failure to hold an attacking trout shall be next to impossible. Notwithstanding this, it is perhaps not too much to say that a perfect minnow flight has not yet been devised. On Plate $\mathbf{I} 2$ are shown four styles which will be found as serviceable as any known systems, the one with the large hook being perhaps most suitable for coloured water, and the flight of hooks for clear water. The minnows are also shown baited in order to make the matter more explicit than could be done by description. No. I is an excellent tackle, and easily baited; No. 2 is also very good, the sliding lead shown on the line obviating the necessity for shot: on the other hand, it requires the use of a baiting needle and a detachment from the trace with each new minnow ; No. 3 is a modification of the Chapman spinner, and was given to me by Mr. J. W. Reffitt, who is an experienced minnow-fisher; and No. 4 is a well-known form, commonly used all over the north.

No. 3 on the Plate-which may be called an improved Chapman spinner-would be difficult to beat for general minnow fishing. In the original Chapman the leaden weight fixed to the vanes or wings soon bursts the skin of the minnow, and is replaced in this improved tackle by a short wire stem which fits the minnow's mouth, the trace being weighted by a small "field" lead, about fifteen inches above the bait. To prevent the minnow slipping down at the head, it should be tied with a piece of black thread in this way:-Take a piece of thread 5 inches long, pass it round the minnow's head so that it catches the gills, tie a double knot on the top of the head, pass through the hole or loop in the head of the spinner, tie again, and cut off the loose ends. A minnow thus fixed will never be lost, unless a trout happens to cut it to pieces, and one minnow will not unfrequently serve for three fish. 
The tying may appear as a disadvantage in the minds of some anglers, who object to any delay on the river's bank, but if about 30 strands of ordinary black sewing thread are cut to about 5 inches in length, and laid lengthwise, and then bound in a faggot with paper and thread, you can draw out a strand as you require it without any trouble.

In spinning a minnow in a falling fresh you may fish almost anywhere, but particularly near the edges of streams and dubs, and about old walls and other places where trout are likely to take shelter. You will find it an excellent plan to make a long throw into the river a little above you, and then drag your minnow quickly straight across the river towards you. You need not be afraid of overdoing it in speed if you are careful not to bring your bait out of the water. Trout are all lying with their heads up stream in from two to three feet of water, and no explanation is necessary to show that a brilliant bait rushing across the river is likely to be visible to more trout than one rushing past them from before or behind; and you will miss fewer fish in this way, because in spinning a minnow up or down you are commonly dragging it away from a fish; in spinning it across you maintain it upon a tolerably straight line which a fish is much more likely to strike. So in clear-water fishing, drag your bait across the water if the size of the river will admit it, and fish the roughest streams. Fish all about the edges of eddies and streams; and in very thin water upon flats throw obliquely up stream and drag your bait quickly round almost to your feet. Give a trout which strikes a spinning minnow - and the same rule will apply to every other case in which a fish takes a natural bait-a couple of seconds before you strike him. It may be worth while to mention that a trout will take a loach or a small bull-head quite as well as a minnow; and in fishing either of these fish, there 
is the advantage that one of them will outlast three or four minnows. But inasmuch as a minnow is brighter to the eye and better to get, he is to be preferred.

A word may be useful as to the best way to preserve minnows when it is impossible to ensure a supply of the live fish. If they are put direct into strong spirit they assume a dull white clouded appearance, owing to the effect of the spirit on the slimy secretion with which the skin is covered. This utterly ruins their brightness. The minnows should be killed by a fillip on the head, sprinkled with salt for not more than ten minutes, and then put into spirit. By this means the slime appears to be dissolved, and the fish retain much of their natural sheen. 
CHAPTER III.

Creeper and Stone-Fly Fishing.

THE creeper is the larva. of the stone-fly, which, as every trout fisher in Yorkshire knows, is aquatic in its origin. All aquatic insects have four stages: the egg, the larva, the pupa, and the imago, or perfect state. The business of the larva is to eat; this it does, practically until it bursts, and assumes the pupa state, and the process is repeated until the insect reaches the imago. It has then six legs, and ceases to grow, its sole remaining business being that of reproduction. In the larval and pupal stages of the stone-flies, which form a branch of the order Neuroptera about which scientific men complain that less is known than about any other class of insects, they live in the water, and after they have attained their perfect condition, they remain near the water in which they were reared, and never travel to any distance from their birth-place, their powers of flight being limited. The male is altogether an inferior insect to the female, his wings being much shorter, and his size, as a rule, only one-third that of his wife. The female carries her eggs about with her for some time before they are laid. They are united together under the abdomen in a small black bundle, which gives the insect a very heavy and cumbrous appearance in its short laboured flights. But as if to add another instance of the wonderful order in Nature's works, this bundle seen under a microscope exhibits several hundreds of eggs fastened together in 
regular order, arranged apparently in strings, and the strings wound firmly into a ball. These eggs are deposited in the water and when, in due time, they are hatched, the young larvæ crawl under stones and other places where shelter can be found. They prefer the running parts of rivers to the deeps, and any little eddy will suit them. Whilst the insects are in this state trout feed ravenously upon them, the surface food which the fish get up to the middle of May being a mere fraction of the amount they pick up in the way of insect larvæ, of which that of the stone-fly is, at all times and in all rivers where it exists, their favourite. When the larvæ of the stone-fly are just assuming the pupæ state, preparatory to becoming perfect flies, theycrawl almost out of the water and take shelter under the edges of stones near the water's edge. At that time, with the exception of the stone-fly itself, and that is not much more killing, the pupæ or creepers are the most magnificent baits you can set before a trout.

It is commonly stated that Yorkshire trout will not take the creeper. To speak plainly, this is arrant nonsense. The writer has himself fished it successfully and regularly on the Wharfe, and it only needs to be fished properly and at the right time to convince anglers that it is simply irresistible. Why, indeed, should the trout in Yorkshire rivers differ from any other? They take the stone-fly ravenously; why not the creeper, which is only another form of that fly? It is fished on the Ribble; it is universally fished on the Eden ; and it is fished on the Scotch rivers, having been introduced there by Carlisle anglers who were laughed at for their pains. But the laughter turned to wonder when at the day's close the creeperfishers had twice as many fish as the fly-fishers.

There is only one part of the season at which the creeper is of use to the angler, and that is when in the course of nature he is about to make a further change in his condition 
and prepares to come out of the water to have room to do it. It has been noticed, and a long succession of generations of trout have noticed it as well as man, that when a creeper feels the desire for wings coming over him he commonly climbs upon a stone-hence perhaps Stone-fly; now, to get upon the stone or out of the river he must leave his shelter under the stone and go abroad; it happens very often that, in the one case he is caught by a little stream too strong for him, and swept into a rapid; in the other he loses his hold upon the stone, and falls back into the water. In both cases the trout are there on the look-out for him. The proper time, therefore, to fish the creeper is just when he begins to move, preparatory to his final stage. This may be told from the time when you begin to find him under stones close to the water's edge, which in warm spring weather will be about the 24th of April. From then up to the appearance of the Stone-fly itself he can distance all comers.

The creeper should be fished with two hooks, his head up the line, i.e. with his front legs just resting on the gut, the bottom hook put in below the thorax, and the upper one right through the side, under the chin, as shown on plate 12. Choose a large creeper for preference, and trout often take the yellow ones better than those which are altogether black. For creeper-fishing your gut trace should be ten or eleven feet long, and you must fish up-stream. The lower and clearer the water is, the more chance of sport. Fishing a line about one and a half times the length of your rod, throw your creeper into the neck of a strong running stream - the stronger the better-just such a place as your eye tells you any helpless atom is likely to be carried to by the force of water; the trout know the place, and are on the look-out. In a fine water your creeper will sink of itself, and you will require no shot on your cast. Trout never take a creeper on the surface, but always underneath. If 
the river is a little swollen, you may use a single shot to keep your bait well below the surface. Cast behind stones round which the river swirls and eddies, and do not strike too quickly; give a couple of seconds after you see your line stop in its passage down the river, and then strike hard. You will find fish take your creeper well also at the thin edges of the rivers-anywhere, in fact where your own perception tells you that the intelligence or instinct of the trout will lead them in search of this dainty food. And the fish you get with it will, as a rule, be the largest fish you have.

The stone-fly is fished pretty much in the same way and the same places, but the majority of anglers prefer a little fresh in the rivers, and the writer is amongst them. In fishing it, if there is any wind at all, it is essential that it should be up-stream. Sufficient has been said about the creeper to indicate the character and habits of this winged transformation, and it is fortunate for the angler that the fly is easily caught as it sits sluggishly or runs upon stones or tree trunks near the edge of the water. In a favourable season, the 2oth of May may be taken as approximately the date of his first appearance. It has already been noticed that there is a great difference betwixt the size of the male and the female flies. Theakston is emphatic in his recommendation of the female as a bait, but it can be shown that the males, familiarly known as Jacks, are to be preferred. Not, perhaps, that a trout will not take one as well as the other, but there are considerations which will appear, which make it advantageous to fish the jacks, and to fish one hook only, as shown in the illustration on plate I2. Get a No. 4 hook, whipped on to fine gut ; insert the point underneath the thorax, pointing the head up the line, and run the hook right down the body of the jack, bringing the point and barb out at the lower 
end of the abdomen. Use no shot: a No. 4 hook will keep a jack sufficiently well down; two hooks tear a jack to pieces, and with one you will find the fly stand any amount of fishing. And now, as to the reasons for recommending the jacks, and one hook only. The latter follows the size of the fly, as a matter of course; but the smaller fly is preferable because you will have quite as many rises at it as you will at the female, and will not miss half the number of fish; simply because it is smaller, that is all. There is naturally more difficulty for a trout to take into his mouth a very big fly than a little one. When a trout takes a stone-fly he sucks it in; the male fly is sufficiently small to be taken at one gulp, but not so the female; the fish holds it, or part of it ; it may be the large wings which are spread abroad that he manages to hold before he recovers himself for another effort to take it down, meanwhile the angler strikes, and the fish is lost. For this reason some of the best stone-fly fishers who prefer the female, break or clip the wings before casting. If you prefer to fish the female fly, you must use two hooks, Nos. 2 or 3. In fishing the stone-fly your gut trace should not be much less than 12 feet long, in order to lessen the chances of flicking the fly off. You will kill the greater part of your fish off the thin edges of the flats; under bushes, or by the trunks of trees, the roots of which reach the water, or about large stones, or, in fact, in any place where again the instinct or intelligence of the trout tells them to look for the flies. The 2oth of June will see the last of the stonefly in nine seasons out of ten, and whilst it is on it may be doubted whether even the beautiful green drake, the mayfly of the south and the midlands, or any other fly which sits upon the water, has equal fascination for trout. 


\section{CHAPTER IV.}

UP-STREAM WORM FISHING.

Tuls is a very scientific and deadly branch of the angler's art, and we are indebted to the late Mr. Stewart for elevating the worm to its position as one of the most killing baits for trout, a bait, too, which in capable hands can be used in weather in which any other method is simply hopeless. A blazing sun, a parched earth, a mere driblet of a river, with water of the very clearest, and the accomplished up-stream worm fisher has sport before him. It is, however, too generally accepted that such weather and such water are alone suitable for the art. As a matter of fact trout will occasionally take a worm in clear water more or less all the year round, as is very well known to every Yorkshire grayling fisher in December and January. And the up-stream worm fisher may undoubtedly find sport as early as April, if he fishes the proper places, which it is needless to say are not the places which he would fish in July and August. The first time the writer ever fished a worm up-stream in clear water happened to be in the third week in May. A long spell of dry easterly winds had reduced the rivers to such a condition that fly fishing was impossible, and notwithstanding the very strong opinion of an old fisherman, the writer and his friend, George Paley, essayed to try the worm after a short lesson from the keeper. The result was that with one angler half a mile a-head of the other, fishing up three miles of a York- 
shire river, we pulled up at noon, with thirty-one trout, all but equally divided. A couple of old hands would doubtless have done better. As usual when we got back, the doubter "would not have believed it, and never knew it done before," \&c. Why should a trout which will take a worm at Christmas and in June, July, and August, and, indeed, at any time in a flood, refuse to take one at any other season? Depend upon it, if you know the places where the trout are lying at the different seasons-a matter which was gone into in the introductory chapter-and you fish the worm in those places, it will not infrequently be taken. It is, of course, no use whatever trying it in the thins in April, but if you let it come trundling down the neck of a stream, or let it be swept along in an eddy, just as you would fish a creeper, it will kill ; though not always, because the bait has not yet been discovered which will do that. The facts are, that as with creeper fishing, up-stream worm fishing in the spring has not hitherto had the attention in Yorkshire which it deserves, for two reasons,-first, perhaps, because fly-fishing is commonly preferred, and second, because under a mistaken estimate of the science required to become an up-stream worm fisher-it has been looked upon as unworthy of notice. But, as every spring angler knows, there are often weeks of easterly winds in which fly-fishing is utterly useless. Then should the worm fisher step in, and he will probably find sport in our rapid and shallow rivers, and he will find also that he has acquired a knowledge of a new branch of angling which will help him to fill his creel sometimes in weather during which any other lureexcept a minnow or a creeper-would be quite worthless.

As in all up-stream fishing, wading is of course essential, half the worm-fisher's art being in keeping behind, and being therefore unseen by the fish. As to your worms-a very important point in two or three respects-they must be of 
the right size and quality, and be fresh, and still sufficiently tough to stand throwing. A trout will always prefer a worm which is perfectly fresh from the earth, if you give him his choice of half-a-dozen, but, unfortunately, the finest angler cannot throw a very tender worm up-stream with any satisfaction to himself, as it must invariably break and become useless after a few casts. The first thing to be considered is the size and the kind of worm best suited to the angler's purpose. And here it may not be out of place to state a fact unknown to many fishermen, that in small streams a grcen worm, usually contemptuously discarded by the worm-picker, will any time kill more trout than a red one. The green worm is not to be recommended for large rivers, or even those of moderate volume, but in tributary becks and the upper parts of rivers you may safely leave the red worms in favour of the green ones. The worms best suited for fishing in the majority of Yorkshire rivers are the small dark-blue headed worms which have not bred. Brandlings are always good, but they are very tender and cannot well be toughened. A period of two days is sufficiently long to toughen a worm for all practical purposes, and at the end of that time he has not lost much of his vitality, and is, to the eye of a trout, no doubt a fairly fresh worm. Shun all preparations of flax for toughening, as they rob the worm not only of its vitality but its gloss. There is no need to keep a worm for a week, and though such a worm will kill, even if kept for very much longer periods, a bright, lively worm is at all times much more likely to tickle the cupidity of a trout.

The quickest and simplest way of preparing worms for the angler is to wash them in a little clean cold water for about three minutes, immediately after taking them from the ground; then put some dry moss in an earthenware pot, with some coarse wet sacking lying on the moss. Put the 



\section{PLATE 12.}

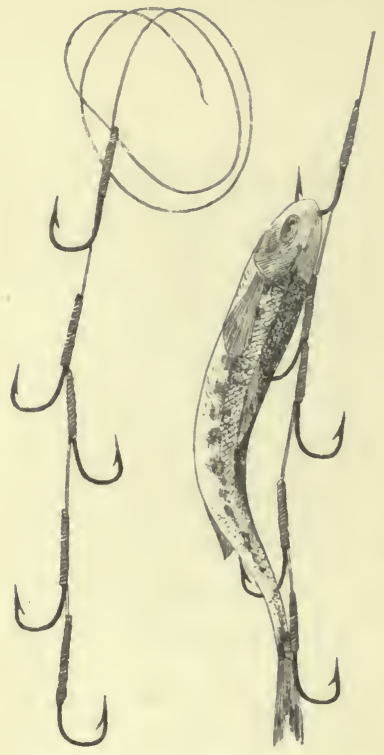

NOI UNBAITED NOI BAITED

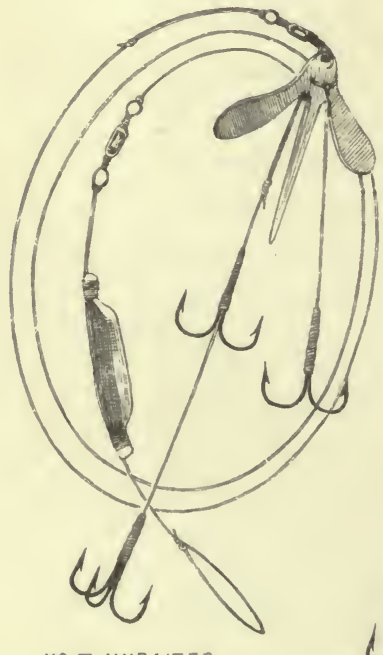

NO 3 UNBAITED
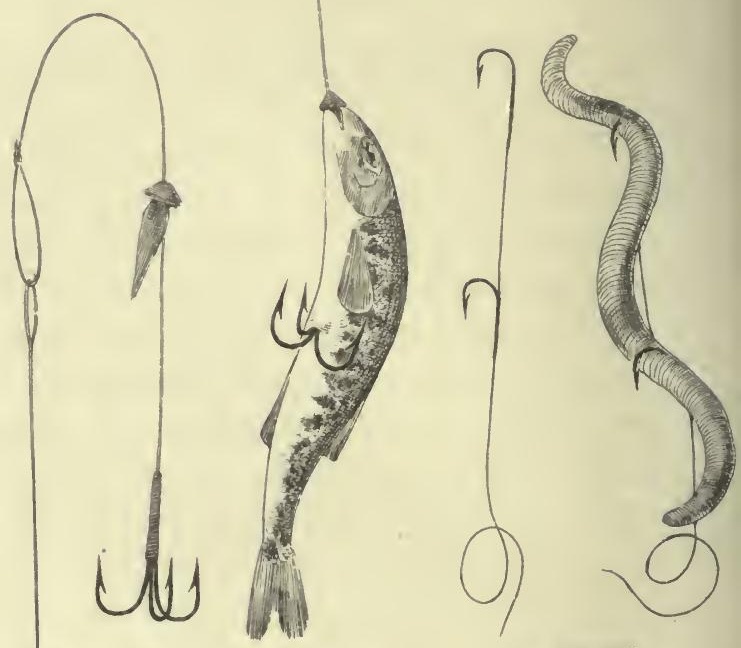

UP STREAM

N:2 UNBAITED NO2 BAITED

WORM-TACKLE
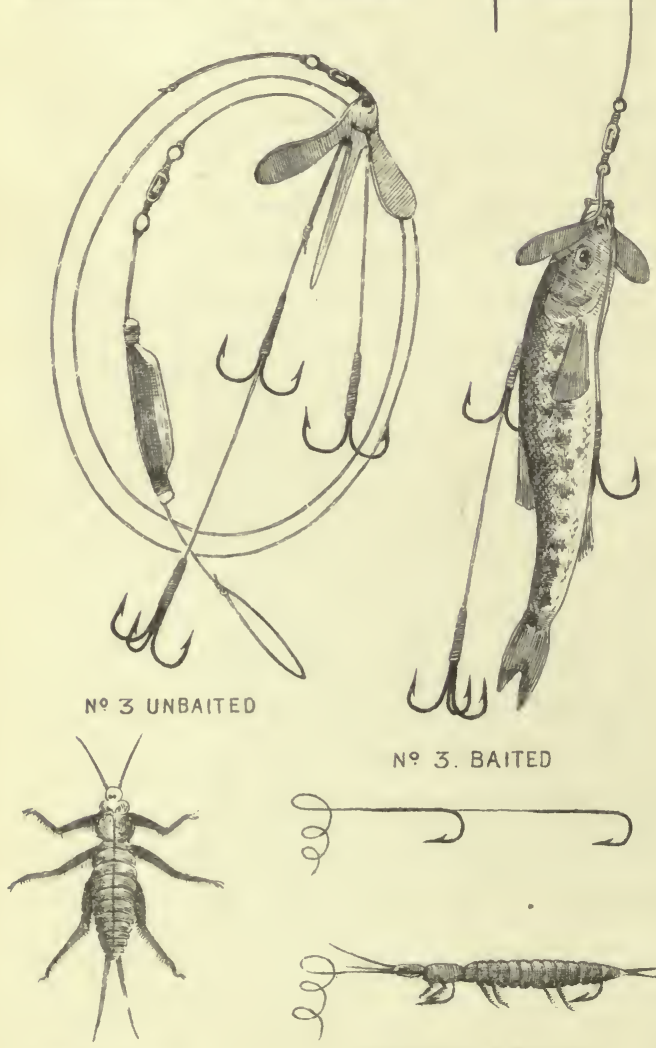

Nㅇ 3. BAITED

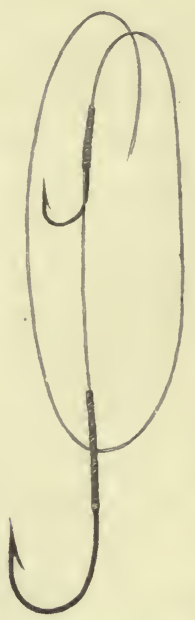

NO 4 UNBAITED
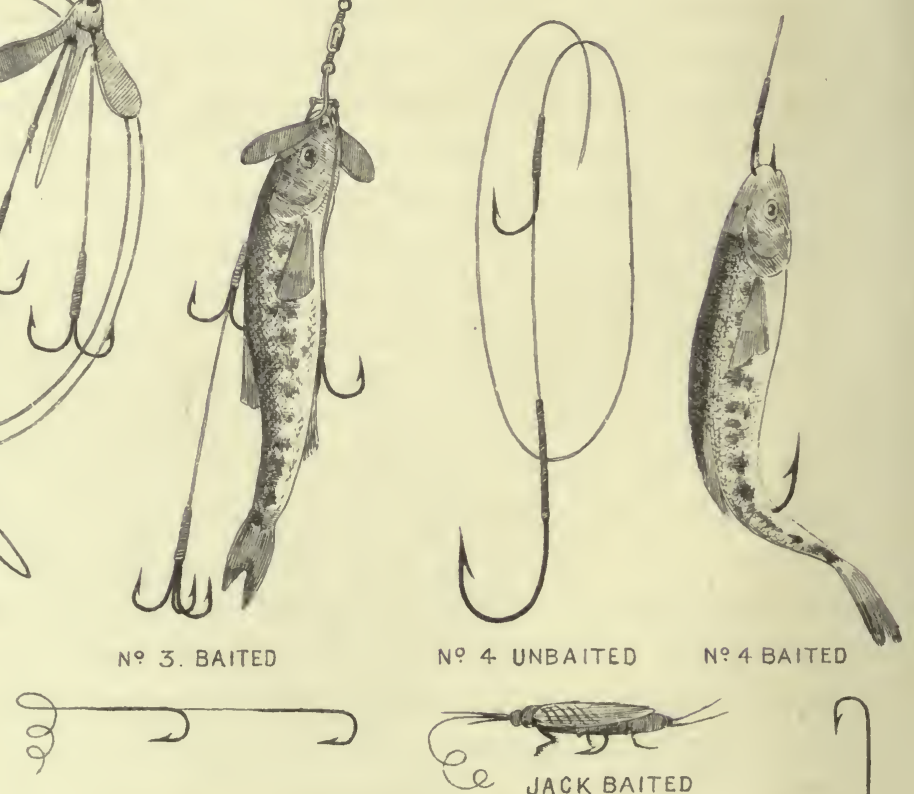

$\bigcap$

J JACK BAITED

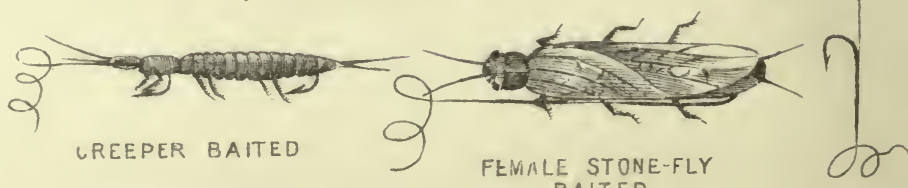


worms on the sacking, and they will find their way through into the moss, scouring themselves as they do so, and they will be tough in two days. An inch and a half to two inches is the best length for worms for this kind of fishing.

An ordinary stiffish fly rod about $\mathrm{I} 2$ feet long will do very well, and your gut trace should be about i I feet long, so as to minimize the chances of flicking off your worm. In spring, when you use the little rapid streams, a single shot, 6 inches from the hook, should be used, but in summer when you get on to the thins and shallows you require no lead; the bait will sink quite sufficiently of itself, and the river will trundle it along naturally into just the places where the fish are lying. In bright summer weather the very shallowest places are not to be ignored, as trout often lie concealed behind a little stone in spots where it would almost appear there is not sufficient water to cover them. Throw a line about one and a half times the length of your rod, and cast either straight up stream or in a slightly oblique direction. Fish two hooks in preference to either one or three; let the upper one be a No. 2 and the lower a No. 3, and bait your worm as shown in plate 12 . Let the stream bring your worm along, and if it stops in its progress, wait a couple of seconds and then strike, remembering that in many cases in which a trout takes a natural bait he commonly follows it down stream a short distance before he takes it. If, as often happens in worm-fishing, you see a fish lying a short distance above you, do not cast your worm above, that is, beyond him. In most cases you will only startle him by so doing. Drop your worm about eighteen inches behind him; in nine cases out of ten he will turn down stream and seize it instantly, being much too intent on his prey to perceive the angler.

An up-stream breeze is always best for worm-fishing, and the weather cannot be too bright and sunny. If you have got 
a down-stream wind, making it impossible for you to fish up, you may fish down if the wind is on the flats and the river is moderately large so as to give you a chance of keeping out of sight. Take your stand at the head of the broken water, as well out of sight as possible, and making a pretty long cast, let your worm be taken quietly down the stream; keep a slack line (which you may do by stepping a yard or two down the river after you have made your cast), or the wind will get under your line and bring the bait to the top. Not infrequently a skilful fisher will make a good dish of fish in this way in very unpromising weather, when circumstances make it impossible for him to adopt the more scientific up-stream method.

Any one who takes up worm fishing in this, its most scientific and interesting form, will be soon convinced of its killing nature, and will probably congratulate himself on the acquirement of this most successful and fascinating branch of the Art of Angling. 


\section{CHAPTER V.}

\section{GENERAL OBSERVATIONS.}

THE principal angling rivers of Yorkshire are the Driffield Beck, the Wharfe, Aire, Derwent, Rye, Ure, Ribble, Nidd, Swale, and Codbeck. With the exception of the firstnamed, all these waters present the same natural characteristics, running merrily over a rocky or gravel bottom in a succession of shallow streams and dubs, with the rare alternation of a deep pool. The Driffield Beck, on the other hand, with one or two smaller streams in the same part of the county, is a slow running river, resembling the chalk streams of Hampshire, and the trout in its waters give a much heavier average weight than those of any other stream in the north of England. The Driffield fish are not to be caught by a novice ; the angler must have served an apprenticeship to dry-fly fishing, and must carefully consider wind and weather, and be an adept in what is, perhaps, after all the most difficult and at the same time the most necessary of all the points in the angler's craft,-the art of keeping out of sight.

Of the other rivers, the best is the delightful Wharfe, hurrying impetuously over its rocky bed in the higher reaches or sweeping gracefully round "Bolton's old monastic pile," where the angler pauses constantly in his craft that his whole soul may take in the glorious scenes which Nature and her partner Time have provided. The Aire, a compara- 
tively small stream up to the point at which it is hopelessly polluted, the Derwent, and the Rye are little inferior to the Wharfe, the Rye in particular being excellent for both trout and grayling. The Ure is best as a grayling river. The Ribble, in its upper waters, has plenty of trout and odd grayling between Sawley and Settle : and the Nidd is not unlikely to figure as one of the best trout streams in the county, owing to sustained and well-directed breeding operations at Knaresborough.

South country anglers who are not altogether unaccustomed to land three, four, or even six-pound fish from the Wey or the Test, contemptuously dismiss the trout of Yorkshire and other north country streams as "herring size," and it must be admitted that, excepting Driffield, any river in the three ridings must be very well whipped before it is likely to produce a three-pound trout. Not that such fish cannot occasionally be found, notably in the lower reaches of the Wharfe, in the Hull, and here and there in the Aire, but these fish have long since been educated to a point far beyond the ability of the ordinary fly-fisher, and by an adverse arrangement of luck they usually fall victims to some local hand who sallies out in a flood, armed with a stick, a piece of string, and an eel-hook, baited with a worm almost as long as a young boa-constrictor.

Putting aside Driffield, as differing from all other Yorkshire waters, the best trout fishing in the county is that of the Kilnsey Angling Club, on the higher reaches of the Wharfe, and that of the Aire Club, above Skipton, the fish on these lengths averaging better than three to a pound. The Kilnsey water holds no grayling, though this fish is plentiful below. The Aire contains grayling, which are increasing, and for the table its trout are probably superior to any in the county.

The size, quality, and quantity of trout are naturally 
dependent on the supply of food in their river, and that in its turn rests mainly upon two things, the rapidity of the current and the general temperature of the water. A shallow river rushing quickly over rock or gravel gathers less nutrition for the fish and produces fewer aquatic plants and molluscs than a slow stream trundling quietly along over a soft muddy bottom. It is very common to hear old Yorkshire anglers lament the decadence of the fishing and the diminution in the size of fish since they were boys fifty years ago: something of this probably belongs to one of those fond hallucinations with which the rose-tinted spectacles of Memory are apt to torment the lean and slipper'd pantaloon, as he looks lovingly back upon "the greenest spot on Memory's waste;" but at the same time it is obvious that the modern system of drainage has undoubtedly affected the rivers, and in all probability the fish. In old days a very moderate "fresh" would keep the river full for a week. Percolating through the natural channels in the land, and gathering microscopic nutrition as it went, the rain found its way gradually and slowly to the river; but in these days the downfall is carried off the land through pipes, as quickly as possible, bringing a sudden fresh, which falls just as suddenly. It is quite possible that as in this way the supply of natural food has been diminished, so the trout have been adversely affected as regards their natural growth.

Then again it must be remembered that almost all the Northern streams have their rise on wild, cold moorlands, high up bare hillsides, many of which approach 2000 feet in height, and that snow is often lying deep in the ravines and gullies up there as late as the middle of April. Melting very gradually, the snow sends down to the rivers a constant accession of cold water which retards the growth of aquatic larvæ and postpones the sprouting of 
aquatic vegetation, if it does not altogether prevent it. All the rivers rising in the West Riding are subject to this influence, and inasmuch as both the aquatic larvæ and the vegetation suffer from the low temperature of the spring water,-a temperature which is proportionally maintained all the year round, owing to the bare and rocky nature of the bleak gathering grounds,-it may be inferred that fish in like manner suffer in common with the meaner life. For these reasons it may be said that we cannot hope to increase the size of trout in the Yorkshire rivers to any great extent, the most obvious requirement being an abundant increase in the food supply, and to this end a free introduction of aquatic plants and molluscs is recommended.

The reader who has gone carefully through the descriptions of the flies given in this book will have noticed that a large majority of them make no attempt to show careful imitations of the natural insects. It would have been possible in many cases to quote a dozen different dressings for the same fly, varying greatly in detail, but arriving in the end at pretty much the same result, as regards size and colour, for I am decidedly of opinion that those two qualities are of far more importance in an artificial fly for any northern river, than that of shape. "Ephemera" is very strong indeed, that nothing but an exact reproduction of the natural fly can be expected to kill; yet I suppose he would not have doubted that a drowned-and therefore a mis-shapen-fly, or an imperfectly hatched fly would be recognized and taken by a hungry trout. In either of these events the shape of the fly is lost, but the size and colour remain. Most old anglers are therefore agreed upon the point that accurate shape may safely be ignored where the size and colour are approximately correct. This being the case, the reason why a hackled fly, made from soft and delicate fibres, embodying these two important essentials, 
has come to be regarded with greater favour in the north than a winged one, becomes obvious.

Again, there can be no doubt that a large number of the winged transformations of the pupæ never reach the surface of the water : either they are imperfectly hatched and are seized as they are borne down the stream, or they are pounced upon by eager trout in their ascent from the bottom of the river to the air. In both cases the hackled fly is quite sufficiently deceptive. The angler will notice, too, in the practice of his art, that the hackled fly will usually be taken under the surface of the stream, and if further illustration is necessary, he will find that on very cold, dark days-when there is not sufficient warmth to hatch out many perfect flies-if the hackled fly be allowed to sink in the stream as far down as possible, and then be quietly worked up in a series of short and gentle jerks, it will often account for fish which can be got in no other way. Most anglers are familiar with the fact that trout will not take, off hand, every natural insect which comes floating along the surface of the river. The fish require to familiarize themselves with its appearance and satisfy themselves thoroughly as to its flavour before they begin to take it greedily. The stone-fly, for instance, is allowed to sail away unnoticed for a week or so after it comes on before trout appear to awake to the fact that there is a feast afloat above them, after which they all with one consent begin to make gluttons of themselves: similarly the dark watchet (the iron-blue dun) sails jauntily away, untouched, or, perhaps, picked up by the swallows, until his appearance and flavour are accepted as good. Against these facts the hackled fly appears as an imitation of an atom with the size, colour and imperfect shape of which the fish have for some time been familiar, as the half-hatched flies became their victims. 
The legal trout season opens on the 2nd of February, and although trout will occasionally take a fly greedily all through that month, and odd fish may be found in very good condition, they have not had sufficient time in which to recover health and strength after the spawning season, and the angler who values his art as a true sportsman should, will give them a longer respite. On many of the Yorkshire waters no fishing is allowed before the Ist of April, and if there is any error in fixing this date it is on the right side. It would be very desirable that the close season for trout should be extended from the 2nd of February to the 15 th of March, the day on which the close season for coarse fish commences.

I may add a sentence on a little matter of detail. The vast majority of fish-hooks are coloured to much too deep a blue. My readers are doubtless familiar with the process of colouring. Experiments I have witnessed convince me that a hook coloured to brown only has two important advantages: first, it more nearly resembles the colour of by far the larger number of flies; and second, it conveys to the eye the impression that it is smaller than a blue one.

If one sentence or idea written in this book serves to stimulate a love of angling, the author will be amply rewarded. Alone amongst all field sports success still depends on man's own skill and wariness, and his finny prey are just as wild and untamable as they were ages ago.

And it is not alone the sport of catching fish which constitutes the charm of Angling: there is in every one of us an innate love of Nature in her purest and her simplest phases: the meanest child will stop instinctively to pull the wayside flower. As of old, Angling is still the Contemplative Man's Recreation : the soothing influence of one bright day 
will linger with us through many a thoughtful hour, and the mind will wander off to the valleys and the hills, to the clear skies and the flying clouds, and memory babbles almost unconsciously of green fields, made musical by the murmuring of a river and the songs of many birds.

TIIE END. 


\section{BOOKS ON ANGLING.}

In the Press, to be Published Shortly.

FIOATING FIIFS AND HOW TO DRFSS THEM. A Treatise on the most Modern Method of Dressing Artificial Flies for Trout and Grayling. With full Illustrated Directions, and containing Ninety Hand-coloured Engravings of the most Killing Patterns, and accompanied by a few Hints to Dry-Fly Fishermen. By FrEDERIC M. HALFORD, "Detached Badger" of The Field, Member of the Houghton Club, FlyFishers' Club, \&c.

CONDITIONS OF PUBLICATION.-A large-paper edition, printed on Dutch hand-made paper, linited to roo copies for England and 50 for America, price 305 ., in vellum binding. (This Edition is exhausted.) Small-paper edition-Demy 8vo, first edition limited to 500 copies, cloth, price 15 s., post free.

SPECIAL NOTICE TO THE TRADE.-The Publishers will supply those Booksellers who have the names of Customers for Angling Works on their books, with PROSPECTUSES, PRINTED IN RED AND BLACK, and a SPECIMEN PLATE OF FLIES, on application.

Now ReAdy. Small 4 to, 364 pages, cloth extra, ros. $6 d$.

FIY-RODS AND FIY-TACKIr. Suggestions as to their Manufacture and Use. By Henry P. Wells. Illustrated.

WATFRSID STrTCIFS. By "RED SPINNER" (Wm. Senior). Imperial 32mo, boards, price Is., post free.

RFCOIIFCTIONS OF FIY-FISHING FOR SAIMON TROUT AND GRAYLING. With Notes on their Haunts, Habits, and History. By EDWARD HAMILTON, M.D., F.L.S., \&c. Illustrated by a Mezzotint Engraving by Francis SEymour HAyDen, Esq., and other Woodcuts. Small post $8 \mathrm{vo}$, printed on handsome paper, cloth extra, $6 s$. , post free.

AN AMATFUR ANGIFR'S DAYS IN DOVE DAIF. Being an Account of My Three Weeks' Holiday in July and August, r884. Imp. 32mo, fancy boards, Is., post free; limp leather-cloth, gilt edges, Is. $6 d$.

AN ANGIFR'S STRANGF PXPFRIFNCFS. By CoTSWOLD IsY, M.A. Profusely Illustrated. Small 4 to, cloth extra. Second and Cheaper Edition, price 3 s. 6 d., post free.

INOTFS ON FISI AND FISFING. By J. J. MANLEY, M.A. With Illustrations. Crown $8 v 0$, cloth extra, 363 pages, leatherette binding, reduced from ros. $6 d$. to $6 s_{.}$, post free.

THP ART OF TROUT FISFING ON TAPID STREAMS. By H. C. Cutcliffe, F.R.C.S. Small post 8 vo, cloth, price $3^{s}$. $6 d$., post free.

FIOAT-FISHING AND SPINNING IN THF NOTTINGHAM STYLE. By J. W. MARTIN, the " Trent Otter." Coloured boards, illustrated, crown 8vo, $2 s .6 d$., post free. New, Revised, and Enlarged Edition.

BRITISH ANGIING rirgs. By Micmakl Theakston. Revised and Annotated by FrANCIS M. WALBRAN. With Woodcut Illustrations, and Plates of Natural Flies drawn from Life. Crown 8vo, cloth, price 5s., post free.

FISHING WITI TrIF IIX. Sketches by Lovers of the Art. With Coloured Illustrations of Standard Flies, collected by C. F. ORvis and A. Nelson Cheney. Square 8 vo, cloth extra, $12 s .6 d$., post free.

Tyr BOOX Or THE ROACF. By the late J. Greville Fennell. In cioth, price $2 s$, post free.

rIT-TYING. By James Ogdre. Post free, 2s. $6 d$.

ESTABLISHED 1877 .

THב IISIING GAZFTTy. PUBLISHED EVERY SATURDAY, Price 2d. Entirely devoted to Angling. If you do not know the paper, send post-card with name and address (and ask for a specimen copy) to the Editor, R. B. MARSTON, I88, Fleet Street, London.

\section{LONDON: SAMPSON LOW, MARSTON, SEARLE, AND RIVINGTON,}

CROWN BUILDINGS, r88, FLEET STREET, E.C. 
wt pul 
RETURN TO DESK FROM WHICH BORROWED

\section{LOAN DEPT.}

This book is due on the last date stamped below, or on the date to which renewed.

Renewed books are subject to immediate recall.

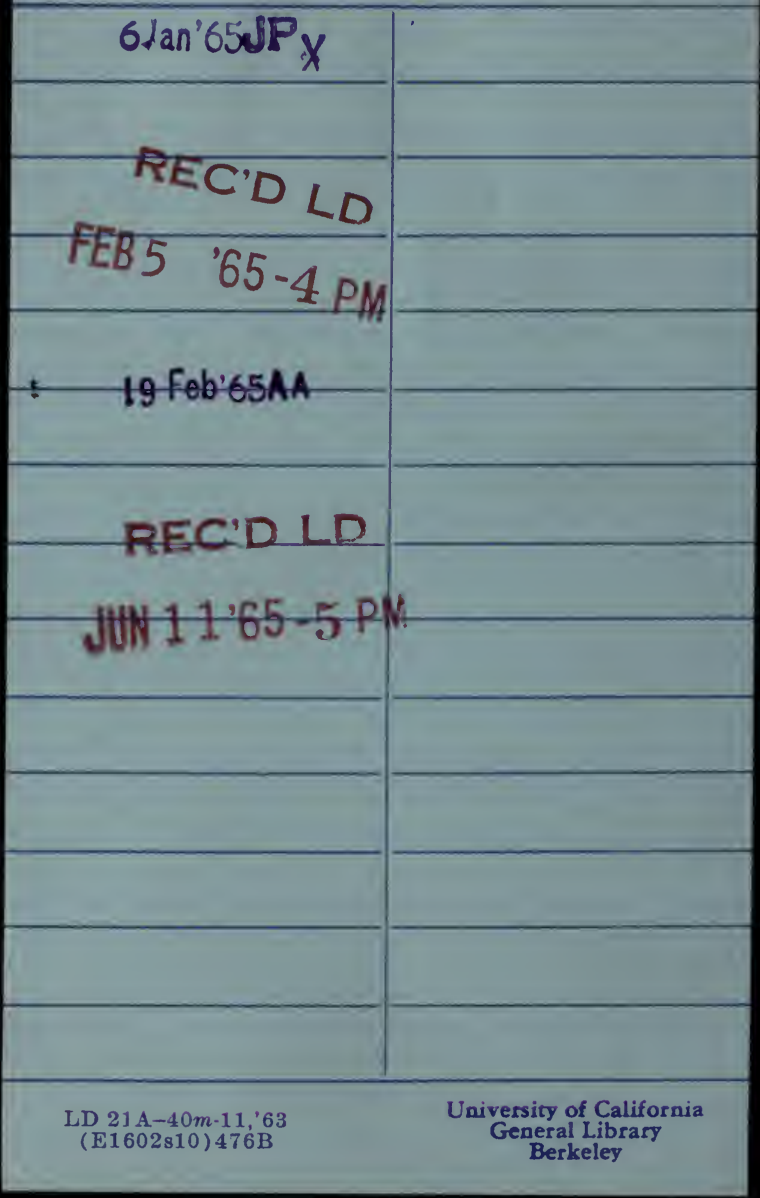


$i$

YC 12496 
Angaris

$\lim _{2}(x)$

$(-3) x^{\prime}$ 